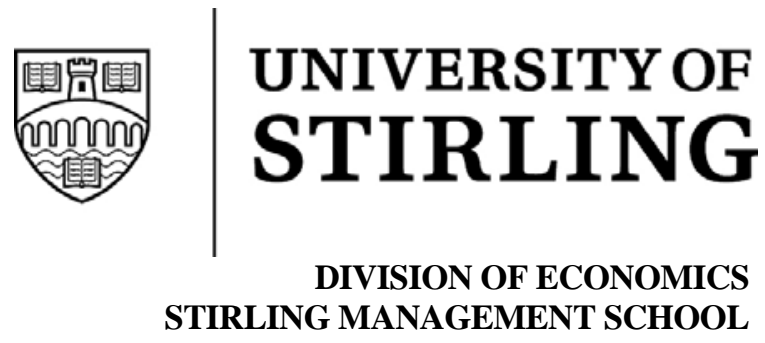

\title{
Catch Me If You Can: \\ Education and Catch-up in the Industrial Revolution
}

Sascha O. Becker

Erik Hornung

Ludger Woessmann

Stirling Economics Discussion Paper 2009-19

September 2009

Online at http://www.economics.stir.ac.uk 


\title{
Catch Me If You Can: \\ Education and Catch-up in the Industrial Revolution*
}

\author{
Sascha O. Becker ${ }^{\dagger}$ \\ U Stirling, Ifo, CESifo, and IZA
}

\author{
Erik Hornung ${ }^{\ddagger}$ \\ Ifo Munich
}

\author{
Ludger Woessmann ${ }^{\S}$ \\ U Munich, Ifo, CESifo, and IZA
}

Existing evidence, mostly from British textile industries, rejects the importance of formal education for the Industrial Revolution. We provide new evidence from Prussia, a technological follower, where early- $19^{\text {th }}$-century institutional reforms created the conditions to adopt the exogenously emerging new technologies. Our unique school-enrollment and factory-employment database links 334 counties from pre-industrial 1816 to two industrial phases in 1849 and 1882. Controlling extensively for pre-industrial development, we use pre-industrial education as an instrument to identify variation in later education that is exogenous to industrialization itself. We find that basic education significantly accelerated nontextile industrialization in both phases of the Industrial Revolution.

Keywords: Human capital, industrialization, Prussian economic history JEL classification: N13, N33, I20, O14

September 8, 2009

* Comments from Bob Allen, Davide Cantoni, Matthias Doepke, Bob Hart, John Komlos, David Mitch, Uwe Sunde, Michèle Tertilt, and seminar participants at Ifo Munich, IZA Bonn, and the Universities of Liverpool, Munich, Stirling, and Swansea are gratefully acknowledged.

${ }^{\dagger}$ Division of Economics, Stirling Management School, University of Stirling, Stirling FK9 4LA, United Kingdom; sascha.becker@stir.ac.uk.

${ }^{\ddagger}$ Ifo Institute for Economic Research, Poschingerstr. 5, 81679 Munich, Germany; hornung@ifo.de.

${ }^{\S}$ University of Munich and Ifo Institute for Economic Research, Poschingerstr. 5, 81679 Munich, Germany; woessmann@ifo.de. 
"But probably education is especially important to those functions requiring adaptation to change.

Here it is necessary to learn to follow and to understand new technological developments."

(Nelson and Phelps 1966, p. 69)

The view that formal education did not play a prominent role in the emergence of new industries in the British Industrial Revolution is well established (Mitch 1999). Surprisingly little attention, however, has been paid to the role of education in the industrial catch-up of the technological follower nations - the whole world except Britain. Models of technological diffusion in the spirit of Nelson and Phelps (1966) suggest that education is the key ingredient to absorb new technologies and adapt to change (cf. Benhabib and Spiegel 2005; Vandenbussche, Aghion, and Meghir 2006). Similarly, most unified growth models stress the role of human capital for the transition to modern growth, at least during the second phase of industrialization (e.g., Galor 2005; Galor, Moav, and Vollrath 2009). It is also sometimes argued that education was important for the transfer of technological leadership from Britain to Germany in leading sectors at the end of the $19^{\text {th }}$ century (e.g., Landes 1969). But the role of education for catch-up during the first phase of the Industrial Revolution is less clear, and thorough empirical evidence is missing for both phases.

This paper provides evidence whether initially better-educated regions within Prussia responded more successfully to the opportunities created by the outside technological changes from Britain. Based on several full Population, Factory, Occupation, and School Censuses conducted by the Prussian Statistical Office, we compile an historically unique micro-regional panel dataset of 334 Prussian counties that spans nearly the whole $19^{\text {th }}$ century. In particular, we cover education and pre-industrial development indicators in 1816, before the start of the Industrial Revolution in Prussia (which is generally placed around the mid-1830s; e.g., Hoffmann 1963; Tilly 1996), as well as education and industrial employment shares towards the end of the first phase of industrialization in 1849 and during the second phase in 1882.

Using the education level observed before the onset of industrialization - which as we show had emerged from historical idiosyncrasies - as an instrument for education levels during industrialization, we find a significant effect of basic school education on industrial employment in both phases of the Industrial Revolution. Our database allows us to distinguish between industrialization in three industries - metals, textiles, and other industries (outside metals and 
textiles) such as rubber, paper, and food. It turns out that in the textile industry, where innovation was less disruptive and child labor more prevalent, education played a minor role during both phases of industrialization. However, it played an important role in the metal and all other industries already in the first phase of the Industrial Revolution, and its importance increased further during the second phase. In line with the technology-diffusion models, we find significant effects for basic education in elementary and middle schools, but not for upper-secondary enrolment or higher-education institutions. Our analyses are motivated by the idea that it may not be arbitrary that Prussia, the educational world leader at the time (Lindert 2004), was particularly successful in industrial catch-up. The results suggest that Prussian educational leadership indeed translated into technological catch-up throughout the $19^{\text {th }}$ century.

The main threat to empirical identification of the effect of education on industrialization arises from the fact that the process of industrialization may itself cause changes in the demand for education. This leads to possible endogeneity bias, the direction of which is not clear a priori. On the one hand, factory production may increase the demand for low-skilled labor, drawing children out of school into factory work. For example, Sanderson (1972) suggests that the Industrial Revolution created new occupations with relatively low educational requirements, which would bias the education estimate downwards. On the other hand, to the extent that the Industrial Revolution increased living standards, education may have become more affordable for broader parts of the population. In addition, Galor and Moav (2006) argue that at least during the second phase of industrialization, the new industrial technologies increased the demand for human capital, which would bias the education estimate upwards.

We identify the effect of education on industrialization in the face of simultaneity among the two by using education in 1816, before industrialization in Prussia, as an instrument for education at the two later periods. This instrument is not affected by changes in the demand for education that emerged during industrialization and thus isolates a part of the variation in education that is not determined simultaneously with industrialization. Under the assumption that pre-industrial schooling is not correlated with other measures that are themselves related to subsequent industrialization, this instrumental-variable (IV) specification estimates the causal effect of education on industrialization in Prussia. We test this assumption and corroborate the validity of the IV specification by showing its robustness against an unusually rich set of covariates indicating the state of economic development before the onset of industrialization. 
Our results are also validated when using an alternative instrument, distance to Wittenberg where Luther used to preach, which yields historically exogenous variation in education across Prussia due to Protestants’ urge for literacy to read the Bible (Becker and Woessmann 2009).

Several additional aspects of our framework facilitate empirical identification, as they introduce exogeneity into the emergence of industrial technologies in Prussia. First, the Industrial Revolution is characterized by production techniques that had not been available before. The new modes of production created a new sector - mechanized industry. This distinguishes analyses of historical industrialization from analyses of agricultural advancement over time and from more general analyses of economic development. Second, most industrial technologies were first applied in Britain, making their advent exogenous from a Prussian perspective. They came as an exogenous "shock" (in the econometric sense of a matter determined outside the variation employed in the model) simultaneously to all Prussian counties once fundamental institutional reforms had freed up the Prussian economy in the first two decades of the $19^{\text {th }}$ century. Third, by using micro-regional data to exploit within-Prussian variation, we can exclude that fundamental institutional or geographical differences determine the capacity for technological adoption, because the Prussian counties share a common basic institutional, cultural, and climatic background. As a consequence, the advent of the industrial technologies in Prussia is like an historical experiment that came from Britain as an exogenous shock.

The remainder of the paper is structured as follows. Section I briefly places the analysis in a theoretical framework and provides historical background. Sections II and III introduce the empirical model and the database, respectively. Section IV presents the results. Section V interprets the results in relation to the existing British evidence. Section VI concludes.

\section{A Leader-Follower Interpretation of Industrialization}

\section{A. The Industrial Revolution and Catch-up to the New Technological Frontier}

The Industrial Revolution ${ }^{1}$ refers to the period of industrialization characterized by profound technological change sparked by such inventions as the steam engine and mechanical spinning, their diffusion, adaptation, and improvement, the rise of the factory system, and accompanying

\footnotetext{
${ }^{1}$ Because of the fundamental economic and social processes of change that occurred everywhere during the industrialization, it has become common to speak of an Industrial "Revolution" not only in the technological leader country Britain, but also in follower countries like Germany (e.g., Borchardt 1973; Hahn 2005).
} 
social changes in households and markets (cf. Mokyr 1999). Modern theory subdivides the Industrial Revolution into two phases: a first phase with skill-saving technological change and minimal educational requirements and a second phase where technological change increases the demand for human capital as skills become necessary for production (e.g., Galor 2005).

In line with this argument, Mitch (1993, p. 307) concludes his seminal review by stating that “education was not a major contributing factor to England's economic growth during the Industrial Revolution,” an argument that applies in particular to formal education and to the first phase of the British Industrial Revolution. Examples of similar assessments include Sanderson (1972), Schofield (1973), Allen (2003), and Clark (2005). As Mokyr (1990, p. 240) famously sums up, "If England led the rest of the world in the Industrial Revolution, it was despite, not because of, her formal education system.” Countless reasons have been advanced for England's technological leadership, ranging from property rights, geography, culture, the biological spread of values, fertility limitation, capital deepening, imperial expansion, and a unique structure of wages and energy prices, up to historical accidents and pure chance (for references, cf., e.g., Galor 2005; Voigtländer and Voth 2006; Clark 2007; Allen 2009). The very question of why England was first to industrialize may even be misconceived and unanswerable because of the uniqueness of the event and the stochastic character of the innovation process (Crafts 1977).

Leaving these discussions aside, we focus instead on industrialization in follower countries. Classical studies such as Gerschenkron (1962) and Abramovitz (1986) have argued that catch-up growth of initially backward countries is inherently different from growth in technological leader countries (cf. Acemoglu, Aghion, and Zilibotti (2006) for a modern exposition). For the rest of the world, the developments in Britain established an outside event that created new technologies and work organizations. Given the change exogenous to follower countries, we suggest that the best way to frame the situation of the rest of the world at the time is a classical technologicalfollower model along the lines of Nelson and Phelps (1966).

Following their model, a string of contributions such as Welch (1970), Schultz (1975), Easterlin (1981), Crafts (1996), von Tunzelmann (2000), Benhabib and Spiegel (2005), and Vandenbussche, Aghion, and Meghir (2006) stresses the leading role of the stock of human capital in the adoption of new technologies and in the ability to deal with changing conditions. ${ }^{2}$

\footnotetext{
2 Sandberg (1979) argues that human capital was a leading factor in late-19 ${ }^{\text {th }}$-century Swedish catch-up. Based on a cross-section of 16 countries, O’Rourke and Williamson (1996) conclude that schooling mattered for catch-up
} 
This is the link we test in this paper. The question addressed is: Once the new technologies had been introduced in Britain, did human capital facilitate their adoption in follower countries? ${ }^{3}$

These technology-diffusion models stress the role of education in creating the ability to adjust to changing conditions, thereby facilitating the adoption of new technologies (see Appendix B for a more detailed discussion of the type of education relevant for industrial catchup). It is conceivable that the direct (static) productive use of skills as well as entrepreneurial and scientific skills played a role in catch-up industrialization. However, in the follower-country context of rapid economic change from outside, basic general skills that open up logical thinking to understand the functioning of the world are particularly relevant in order to perceive and solve new problems. Therefore, in line with the leader-follower models - and because the average level of secondary and higher education was very low in the $19^{\text {th }}$ century - we focus on basic education in this paper. In addition, these models predict that the adoption of new technologies, and thus industrialization, is a function of the stock of, rather than the change in, human capital. Section $\mathrm{V}$ will discuss how the role of education in the leader country Britain may (or may not) have differed from follower countries.

\section{B. Institutional Reforms and the Emergence of Industrialization in Prussia}

The main reason why industrialization in Prussia started considerably later than in Britain is the institutional divide constituted by the Napoleonic reign in Prussia in 1806-1813. ${ }^{4}$ Whereas the prior institutional structure can be described as a stiffened absolutistic and feudal regime, a series of modernizing institutional reforms based on the ideas of the Enlightenment were enacted in response to the military defeat of Prussia in 1806. These institutional reforms are sometimes described as a "revolution from above" and were "aimed at fostering private initiative through removing guild restrictions on trade as well as a sweeping set of anti-feudal land and labor

in 1870-1913, but only modestly. Taylor (1999) confirms this result for the same period with panel data for seven countries, but stresses the considerable limitation of historical cross-country education data. Lundgreen $(1973,1976)$ provides a descriptive account of aggregate education levels in Prussia from 1864-1911.

${ }^{3}$ Empirical evidence on the role of education in the Industrial Revolution is largely refined to the leader country Britain (cf. Mitch 1999), and even there suffers from severe data constraints (see Section V below). Exceptions of econometric studies of the role of education in industrialization outside Britain include A'Hearn (1998) on Southern Italian textile factories in 1861-1914, Rosés (1998) on Catalan cotton factories in 1830-61, and Bessen (2003) on textile firms in Lowell, Massachusetts around 1842. Note that all these contributions focus on the textile sector and on a specific region, and that their interpretation may be affected by the endogeneity issues discussed in this paper.

${ }^{4}$ A positive interaction between the institutional framework and education in promoting economic development has both been emphasized theoretically and found in modern data (cf. Hanushek and Woessmann 2008). 
reforms” (Lenoir 1998, p. 22). As Tilly (1996, p. 98) puts it, “the Stein-Hardenberg Reforms constituted an important, indeed, crucial, step forward in German industrialization.” The most important institutional changes were the abolishment of serfdom, particularly for peasants, and the introduction of freedom of land tenure, which together created individual property rights in land and labor (e.g., Pierenkemper and Tilly 2004); the introduction of freedom of occupational choice and of business establishment, which created freedom of trade (e.g., Henning 1995); improvements in equality before the law; emancipation of the Jews; introduction of substantial municipal self-government; and, in 1818, the abolishment of internal tariffs (followed by customs unions with other German states that culminated in the Zollverein in 1834).

Before Napoleonic times, important institutional preconditions for free business, economic change, and industrial development were missing in Prussia. Thus, the new order of Europe set up at the Congress of Vienna in 1815 after the defeat of Napoleon establishes a landmark for the start of the possibility to industrialize in Prussia (e.g., Kiesewetter 2004). Once Prussia had opened up institutionally, the changes that had emerged in Britain approached all parts of Prussia in a similar way. The reforms that were initiated under French occupation "were akin to an exogenous change in institutions unrelated to the underlying economic potential of the areas reformed” (Acemoglu, Cantoni, Johnson, and Robinson 2008, p. 2). An additional reason for the delay of industrialization in Prussia relative to Britain has been seen in the long span of revolution and war in Continental Europe from 1789 to 1815 (Landes 1998). Furthermore, Napoleon had established the Continental System that embargoed Britain from the continent between 1806 and 1814. Once this ban of trade and interaction with Britain was abolished, Prussia became able to import British technologies (e.g., Radkau 2008).

When dating the inception of the Industrial Revolution in Prussia, most history scholars agree that the first phase of industrialization in Prussia started around the mid-1830s (e.g., Hoffmann 1963; Tilly 1996). The earliest chronological dating stems from Kiesewetter (2004) who argues that in a regional perspective, the defeat of Napoleon 1815 may be viewed as the very earliest beginning of industrialization in some regions. In line with the argument of the institutional divide above, this enables us to view school enrollment in 1816 as a measure of education observed before the onset of the Industrial Revolution in Prussia.

Prussian industrialization is generally subdivided into two phases, with the first one dating roughly between 1835 and 1850 and the second one in the second half of the $19^{\text {th }}$ century. 
According to some observers, around 1850 the technological gap between Britain and Prussia "had been more or less closed” (Kindleberger 1995, p. 231). In the second phase, the adoption of imitated, imported technologies was expanded towards more autonomous developments of industrial pioneers, for example in the chemical industry and in electrical technologies (e.g., Hahn 2005). The German revolutions in $1848 / 49$ also establish a significant break. We thus view 1849, for which unique factory and education data are available, as a useful landmark towards the end of the first phase of industrialization in Prussia.

\section{The Empirical Model}

\section{A. Basic Setup}

The leader-follower relationships discussed above, as modeled by Nelson and Phelps (1966) and subsequent growth models (cf. Benhabib and Spiegel 2005), require a specification where the level of, rather than the change in, education affects industrialization. ${ }^{5}$ Therefore, our basic model expresses industrialization $I N D$ towards the end of the first phase of the Industrial Revolution in 1849 as a function of the level of education $E D U$ and other explanatory factors $X$ :

$$
I N D_{1849}=\alpha_{1}+\beta_{1} E D U_{1849}+X_{1849}^{\prime} \gamma_{1}+\varepsilon_{1}
$$

where $\varepsilon$ is a random error term and $\beta$ is the coefficient of interest. We will estimate this model using the cross-section of Prussian counties, effectively exploiting Pollard's (1981, p. 14) assessment that the Industrial Revolution was "a regional phenomenon" (cf. Hohorst 1980 and Kiesewetter 2004 for similar arguments for Germany). In addition to using indicators for industry as a whole as the dependent variable, we can also perform the analyses for three separate industries: textiles, metals, and the group of all industries outside textiles and metals. In addition to 1849, we also measure the level of industrialization at a later stage, during the second phase of the Industrial Revolution in 1882.

The main threat to empirical identification is that ordinary least squares (OLS) estimates of $\beta$ may be subject to endogeneity bias. In particular, the process of industrialization may itself cause changes in the demand for education, giving rise to possible reverse causality. The estimated

\footnotetext{
5 This mirrors specifications in research on modern growth that relate the level of, rather than the change in, human capital to growth (cf. Krueger and Lindahl 2001). Note that such a relationship cannot be identified by standard fixed effects panel models, which take out level effects.
} 
coefficient on education would be biased downwards if factory production increased the demand for low-skilled labor and kept children out of school by drawing them into factory work. Thus, the British Industrial Revolution seems to have created new occupations with lower educational requirements than the existing ones (Sanderson 1972; cf. West 1978 for a discussion). But the estimated coefficient on education may also be biased upwards if the Industrial Revolution increased living standards to the extent that education became more affordable for the broad masses, or if the new industrial techniques increased the demand for human capital. The latter is often argued at least for the second phase of industrialization (cf. Galor 2005). In sum, not even the direction of any possible bias, let alone its size, is obvious a priori.

\section{B. Obtaining Exogenous Educational Variation from Pre-Industrial Education Levels}

To address the worry that education may be endogenous to industrialization itself, we suggest an instrumental-variable strategy where education levels observed before the industrialization serve as an instrument for education levels during industrialization. Thus, in equation (1) we instrument education $E D U$ in 1849 by education $E D U$ before the Industrial Revolution in 1816:

$$
E D U_{1849}=\alpha_{2}+\beta_{2} E D U_{1816}+X_{1849}^{\prime} \gamma_{2}+\varepsilon_{2}
$$

This first stage allows us to isolate that part of the variation in education in 1849 which can be traced back to pre-industrial variations in education. Such an approach is enabled by our unique panel dataset which includes education data before the Industrial Revolution. We can then follow the same Prussian counties during the two phases of the Industrial Revolution.

A fundamental point is that the Industrial Revolution is about new industrial technologies, both technical and organizational, which simply did not exist previously. Exogeneity comes from the fact that mechanized industrial production developed outside Prussia, in Britain. For the Prussian counties, its advent constituted a common exogenous shock (in econometric, not historical terms). We effectively have a pre-set distribution of education across the country and then observe what happens to the different counties when the shock of new technologies from Britain hits Prussia after it opens up through the institutional reforms of the Napoleonic era. ${ }^{6}$

\footnotetext{
${ }^{6}$ Conceptually, this approach is in the spirit of the analysis of Blanchard and Wolfers (2000) of European unemployment where common shocks interact with preconditions that differ across observations.
} 
While we do not fully model the source of the variation in our instrument $E D U_{1816}$, it seems clear that - apart from the systematic variation stemming from distance to the Protestant hub Wittenberg which we use below - the educational variation that existed in Prussia in 1816 stems from an accumulation of idiosyncrasies of local rulers rooted deep in history that are exogenous to our topic of investigation. This can be best depicted by a number of examples of sources of substantial educational variation between neighboring counties, as evidenced by the four rectangles in Figure 1 which shows an educational map of Prussia in 1816. In each case, historical peculiarities that are unlikely to be otherwise correlated with features relevant for later industrialization gave rise to significant and lasting differences in schooling.

For example, the lightly shaded counties in the center of rectangle 1 form Ermland, a mostly sovereign diocese before it came under Prussian rule in the first Partition of Poland in 1772. Ermland, which remained thoroughly Catholic, was surrounded by the Protestant Dukedom of Prussia. The Ermland counties had enrollment rates between 20\% and 25\% in 1816, whereas the surrounding Protestant counties - in line with Luther's urge for education - had enrollment rates of $75 \%$ in the west, $71 \%$ in the south, and $65 \%$ in the east. Note that while the religious source of this educational variation is the same as the one employed in our second identification approach (see below), this variation is not driven by distance to Wittenberg, but by historical peculiarities.

Another interesting neighboring difference is observed in the westernmost part (rectangle 2), where the starting point is virtually opposite. The areas of Geldern and Moers in the far west had been part of Prussia since 1702/03 (and had a Protestant share of about one quarter). However, apparently due to a lack of interest and enforceability in the western exclaves, the Prussians did not enforce their schooling ideals during the $18^{\text {th }}$ century, so that the desolate state of the school system - evident in the low school enrollment figures in our data - became a topic of many school inspectorate reports in the early 1800s (Nagel 2004). By contrast, the neighboring counties to the east - which were part of the Prince-Bishoprics of Cologne and particularly Münster - although thoroughly Catholic and annexed by Prussia only in 1815, already had enrollment rates of $70 \%$ to $76 \%$ in 1816 . Interestingly, the source of the relatively high level of schooling throughout the Prince-Bishopric of Münster can be traced back to the Catholic (!) order of the Jesuits, who used costless comprehensive schooling as a means to restore the population back to Catholic faith in the Counter-Reformation after 1588 (Schönemann 1993). 
The counties in rectangle 3 constitute the area of Swedish Western Pomerania, which was governed by the Swedish kings from the Thirty Years' War until 1720 (although it was not a formal part of Sweden, but of the German Empire). But while the southern part (later called Old Western Pomerania) came to Prussia in 1720, the northern part (New Western Pomerania) divided by the river Peene - came to Prussia only in 1815. Sweden had difficulties enforcing a tax system in its territory and thus somewhat neglected the financial equipment of its representatives. As a consequence, while the southern counties that had been part of Prussia for a century had enrollment rates of $72 \%$ to $77 \%$ in 1816 , enrollment rates in the northern counties, which had just joined Prussia, were still as low as $17 \%$ to $34 \%$.

The counties of Liebenwerda and Hoyerswerda (west and east, respectively, in rectangle 4) had been part of the Lutheran heartland Electorate of Saxony for centuries before they joined Prussia at the Congress of Vienna in 1815. However, Hoyerswerda, as part of the Oberlausitz, was not directly subject to Saxon law because it had retained the right to maintain a local feudal tribute system and - in contrast to the Electorate of Saxony - placed little emphasis on education. Accordingly, in 1816 its enrollment rate of $44 \%$ was substantially below the $80 \%$ of neighboring Liebenwerda. $^{7}$

These examples illustrate that a multitude of idiosyncratic sources had given rise to the crossPrussian variation in education levels in 1816. While historical differences in rule had given rise to the variation in pre-industrial education levels, all counties are subject to the same Prussian rule after 1815. We thus view the variation in our instrument $E D U_{1816}$ as exogenous to the error term of our model, corroborating instrument validity.

A potential remaining threat to this IV identification could still emerge if the instrument was correlated with the error term $\varepsilon_{1}$ of the industrialization model - be it through correlated idiosyncrasies or for other reasons. If pre-existing education were correlated with other important omitted factors that drive the subsequent adoption of industrial technologies, such as pre-existent institutional features of the economy or geographical features, the IV estimate of the education coefficient might still be biased.

\footnotetext{
${ }^{7}$ Another leading example of a Dukish quirk, although just outside Prussia in the German Empire, was Ernest I, the Pious, Duke of Saxe-Gotha, who - driven by his Lutheran faith - introduced effective compulsory schooling in his territory in 1642, still during the Thirty Years' War. It was proverbial that the Duke's peasants were better educated than the nobility elsewhere, and public saying has it that there was no one in his Dukedom unable to read and write when he died.
} 
To rule out such remaining biases, we test whether our IV estimates are robust to including a set of indicators of pre-industrial development $Y$ measured at the county level at the same time before the Industrial Revolution as pre-industrial education:

$$
I N D_{1849}=\alpha_{3}+\beta_{3} E D U_{1849}+X_{1849}^{\prime} \gamma_{3}+Y_{1816}^{\prime} \mu_{3}+\varepsilon_{3}
$$

Here, our particularly rich database containing pre-industrial development measures observed at the county level around 1816 comes into play, covering the spread of pre- and proto-industrial technologies such as looms, brick-making plants, and watermills, urbanization, availability of resources for mining and weaving, measures of agricultural development including livestock counts and agricultural employment, measures of public infrastructure like buildings and paved streets, and access to navigable water measured by rivers and transport ships. While we control for proto-industrialization, it should be noted that industrialization itself, in the sense used in this paper of the new mechanized production techniques that had recently emerged in Britain, did not exist in Prussia in 1816 (as evidenced by the fact that the 1816 Census does not list any industrial occupations, as in the 1849 Census). We additionally check robustness to controls for geographical measures, religion as a possible remaining cultural variation, and rounds of Prussian annexations (to proxy for possible remaining variation in institutional implementation).

\section{Additional Specifications}

We also experiment with a second approach to identification, proposed by Becker and Woessmann (2009) for the analysis of Protestant economic history. They observe that at the times of Martin Luther, Protestantism in Prussia had a tendency to spread in circles around Wittenberg, where Luther preached that every Christian should be able to read the Bible. They show that as a consequence, distance to Wittenberg gives rise to a decreasing prevalence of education in Prussia, and that Protestantism is unlikely to have had substantial economic effects besides its indirect effect through education. Based on this observation, we can use distance to Wittenberg WITT as an alternative instrument for education in the first stage of our model:

$$
E D U_{1849}=\alpha_{4}+\beta_{4} W I T T+X_{1849}^{\prime} \gamma_{4}+\varepsilon_{4}
$$

The advantage relative to our main approach is that this instrument directly models the source of the particular variation in the endogenous independent variable. But the specification requires the 
identifying assumption that Protestantism affected industrialization only by increasing education, which is in line with the findings in Becker and Woessmann (2009).

We are able to estimate the models both for the first phase (1849) and for the second phase of industrialization (1882), where the latter depicts the full effect of education for both phases. To depict the impact of education on the progress of industrialization during the second phase (between 1849 and 1882), we can estimate

$$
I N D_{1882}=\alpha_{5}+\beta_{5} E D U_{1882}+\lambda_{5} I N D_{1849}+X_{1882}^{\prime} \gamma_{1}+Y_{1816}^{\prime} \mu_{5}+\varepsilon_{5}
$$

which holds the level of industrialization already achieved in 1849 constant. This specification identifies the additional effect of education on industrialization during the second phase.

\section{Prussian County-Level Data Spanning the $19^{\text {th }}$ Century}

\section{A. Constructing a Panel Database}

The suggested empirical models require an unusually rich set of data. Not only do we need regional data on the levels of education and industrialization (as well as standard demographic and geographic controls) for two phases of industrialization, but also on the levels of education and general development at a point in time that pre-dates the Industrial Revolution. To that extent, we have compiled a database for all Prussian counties for the years 1816, 1849, and 1882, effectively allowing us to observe micro-regional development throughout the $19^{\text {th }}$ century.

The data originate from censuses conducted by the Prussian Statistical Office, founded in 1805, and are available at the county level in archives (see Appendix A for details). The first released full-scale census is the Population Census in 1816, which - together with 1819 and 1821 surveys - provides us with data on education, demographics, and a host of development indicators. In 1849, the statistical office conducted not only another Population Census, but also a Factory Census that provides us with data on industrial employment. We are not aware that these data have been used at all before in microeconometric analyses. Finally, we add data from an Occupation Census in 1882 which provides detailed information on sectoral employment.

We structure our data by the 334 counties existent in 1849. Despite some changes in the administrative boundaries of counties between 1816, 1849, and 1882, we were able to link the data consistently over time, yielding a panel-structured database. Appendix Table A1 provides detailed descriptions of data sources and definitions for the variables employed in our analyses. 


\section{B. Main Variables and Descriptive Statistics}

We measure industrialization towards the end of the first phase of the Industrial Revolution by factory employment as a share of total county population in 1849. In the Factory Census, the statistical office reports employment in 119 specific types of factories. We combine these into three industrial sectors: metalworking factories; textile factories; ${ }^{8}$ and other factories (outside metals and textiles), such as those producing rubber, paper, food, wood, and wax. ${ }^{9}$

Our measure of industrialization in the second phase of industrialization is manufacturing employment as a share of total county population in 1882. The sectoral classification is directly provided by the statistical office in the Occupation Census. A downside of this classification relative to the factory count of 1849 is that the 1882 measure includes craftsmen and artisans who may not necessarily perform industrial work. Again, we subdivide the manufacturing sector into metals textiles and all manufacturing except metals and textiles. In both phases of industrialization, we can also calculate the share of manufacturing workers in the occupied labor force, rather than in the total population, of each county.

Our education measures before and in the first phase of the Industrial Revolution refer to 1816 and 1849. They indicate the enrollment rate in elementary and middle schools, measured as the enrollment count in elementary and middle schooling as a share of the population aged 6 to 14 years, which is the relevant school age in Prussian elementary and middle schools. Both enrollment and age-specific population data come from full Population Censuses. We use school enrollment in 1849 as a proxy for the education level of the labor force in 1849. To cover the educational background of the full age range of the 1849 labor force, we also experimented with using a simple average of 1816 and 1849 enrollment instead of 1849 enrollment as the measure of education in 1849, yielding the same qualitative results. ${ }^{10}$

The education measure in the second phase is a more direct measure of the education level of the working-age population, namely the adult literacy rate, available (for the first and only time) in the 1871 Population Census. It measures the share of those who are able to read and write

${ }^{8}$ In the weaving factories, we exclude workers employed on hand-driven looms and only count mechanical looms, in line with a definition of industrialization as development towards machine-driven work.

${ }^{9}$ We have also experimented with excluding factories below a certain employment number from the analyses, such as factories with less than 5 or 10 workers; our qualitative results were unaffected.

${ }^{10}$ One can also think of our IV specification, which instruments 1849 enrollment by 1816 enrollment, as a means to deal with measurement error by using two imperfect proxies for the education level of the 1849 labor force, where the instrument additionally ensures that no variation is used which is caused by industrialization. 
among the population aged 10 years or older. We also experiment with data on upper-secondary enrollment and university location at the three points in time.

The 1816 census contains a wealth of additional information, including data on population demographics, religion, livestock, and occupations. We compile an extensive set of indicators of pre-industrial development from this and other sources, including indicators for pre-industrial production and endowment, natural resources, transportation infrastructure, urbanization and population density, and other historical patterns of development (see Appendix A for details).

Table 1 reports basic descriptive statistics for the variables used in our analyses. The education data support the view of a relatively advanced educational development in Prussia throughout the $19^{\text {th }}$ century. The average enrollment rate in elementary and middle schools is $58 \%$ in 1816 and increases to $80 \%$ in 1849 . Still, there is enormous variation across counties, ranging from 3\% to 95\% in 1816 (cf. Figure 1) and from 33\% to 99\% in 1849. The average and distributional statistics of 1849 school enrollment and 1871 literacy are surprisingly similar.

Industrialization in 1849 as measured by the share of factory workers in total population is relatively low at $1.8 \%$ on average. Half of this is in industries outside metals and textiles, $0.6 \%$ in metals, and $0.3 \%$ in textiles. Across counties, the measure varies from $0.4 \%$ to $18.5 \% .{ }^{11}$ As a share of the occupied labor force, factory employment amounts to $2.8 \%$. By 1882, $11.6 \%$ of the population (or $27.0 \%$ of the occupied labor force) are employed in manufacturing, combining $3.1 \%$ in metals, $3.9 \%$ in textiles, and $4.6 \%$ in other manufacturing sectors. All industrialization measures expose substantial regional variation (cf. Appendix Figures A1 and A2).

As a first descriptive indication of the associations among the education and industrialization variables, Table 2 reports pair-wise correlations. The education measures at the different points in time are strongly related to each other. They are also significantly associated with the aggregate measures of industrialization at the two phases, most obviously in the industries outside metals and textiles. Industrialization is also strongly associated over time, with the correlations within each of the three sectors being much stronger than across sectors.

\footnotetext{
${ }^{11}$ Given the skewness of the distribution of the dependent variables, we also estimated specifications using their logarithms, obtaining the same qualitative results.
} 


\section{Results}

\section{A. The First Phase of Industrialization}

The first part of Table 3 reports OLS regressions across the 334 Prussian counties in 1849, towards the end of the first phase of industrialization. The dependent variable measures industrialization by employment in factories as a share of the total county population in 1849, which we can subdivide into three sectors: all factories outside metals and textiles, metal factories, and textile factories. We start with a parsimonious model that controls only for basic demographic and geographic measures, namely the shares of the population aged below 15 and above 60 and the size of the county area, each of which might be expected to be negatively associated with industrialization.

The results reveal that towards the end of the first phase of the Industrial Revolution, the share of factory workers is significantly positively associated with the enrollment rate in elementary and middle schools. ${ }^{12}$ When looking into the three sectors, this is particularly true for industries outside metals and textiles, and also for the metal industry, whereas there is no such significant association of education with industrialization in the textile industry. ${ }^{13}$ However, as discussed above, any such OLS association may be biased because school enrollment in 1849 may be endogenous to industrialization in 1849, with the direction of the bias unclear.

To address this issue, the remaining columns of Table 3 report IV estimates that instrument school enrollment in 1849 by school enrollment in 1816, before the onset of the Industrial Revolution. The instrument is not affected by changes in the demand for education that emerged during industrialization, which came exogenously from the industrial leader Britain. Under the assumption that 1816 school enrollment is not correlated with other measures that are themselves related to subsequent industrialization, these IV estimates depict the causal effect of education on industrialization in Prussia. We will test this assumption below.

The reduced-form relationship between 1816 school enrollment and 1849 total factory employment (column (5)) is significantly positive (significance reaches the 1 percent level in the

\footnotetext{
12 Throughout the paper, standard errors are clustered at the level of the 280 units of observation in the 1816 data that we use below (see Appendix A for details).

${ }^{13}$ Although the dependent variables of our models are proportions that vary between 0 and 1 , predicted values of a linear regression may fall outside the $[0,1]$ interval. We thus also used the logarithm of the odds ratio of the sector share as an alternative dependent variable that is not subject to this problem. Results are qualitatively the same.
} 
industries outside metals and textiles, not shown). As the first stage (column (6)) shows, 1816 enrollment provides a powerful instrument for 1849 enrollment. Each percentage point higher 1816 enrollment is associated with 0.26 percentage point higher 1849 enrollment. The secondstage estimate for all industries is statistically significant and close to the OLS estimate. But this effect is now fully borne by the industries outside metals and textiles, whereas the estimate in the latter two sectors is not statistically significant. We will discuss the size of the estimates below.

\section{B. Is Pre-Existent Education Exogenous?}

For pre-industrial levels of education to be a valid instrument, we have to assume that there are no other features correlated with education in 1816 that also correlate with subsequent industrialization. In order to test this assumption, we extend our model with a host of indicators of pre-industrial development, testing whether the IV estimates are robust to their inclusion.

The indicator of pre-industrial development most often used in the literature is urbanization, as cities could only be supported where agricultural productivity was high, specialization advanced, and the transport systems well developed (cf. Bairoch 1988; Acemoglu, Johnson, and Robinson 2002). Thus, the first column of Table 4 adds the share of a county's population living in cities in 1816, defined by the Prussian Statistical Office as having city rights and privileges (which applies for roughly 1,000 Prussian cities). While urbanization in 1816 is indeed significantly associated with subsequent industrialization, the estimated effect of education is hardly affected. Very similar results are obtained when measuring urbanization by the population share living in one of the 172 large or medium-sized cities, defined as having more than 2,000 inhabitants (not shown). Population density, measured as inhabitants per square kilometer, does not enter the model significantly or affect the education estimate.

By 1816, proto-industrial technologies were already emerging. To account for their possible impact, column (2) adds the number of looms per capita in 1819 as a leading pre-industrial technology. Looms in 1819 enter the model significantly but do not affect the education estimate.

Other indicators of pre-industrial technologies, such as the number of brick-making plants and watermills per capita in 1819, do not enter the model significantly (not shown).

Several industries are highly resource dependent, such as those requiring coal for energy or specific metals for production. We are not aware of measures quantifying the availability or potential of mineral resources around 1816. However, we know the number of steam engines 
employed in mining in 1849. To the extent that actual resource exploitation, and in particular the use of steam engines, is endogenous to industrialization itself, using this measure to control for resource availability over-adjusts our specification. However, as column (3) reveals, if anything, the estimated effect of education increases when steam engines in mining per capita are included, even though the latter is positively associated with factory employment. Another available proxy for mining is the number of fatalities in mining per capita in 1853, which, when used as an alternative to the steam-engine measure, also enter the model significantly, but do not affect the qualitative result on education (not shown). Results are also robust when adding a dummy for the 53 counties with any mining incidence according to the steam-engine and fatalities measures. Alternatively, we can exclude workers in iron, wire, brass, smelter of other metals, steal, and copper-hammer factories from our factory count, yielding similar results (not shown). ${ }^{14}$

In fact, any issues of access to mineral resources would only affect the result on education if the instrument, school enrollment before the onset of the industrialization, were significantly correlated with the geographical distribution of deposits of mineral resources. This seems quite unlikely, given that the resources of interest only became of real relevance during and because of the Industrial Revolution. In fact, school enrollment in 1816 is uncorrelated with the different indicators of later mining - the indicator for use of steam engines in mining in 1849, ironworking factories in 1849, and mining in 1882 - (all $p$ values exceed 0.75 ), and there is even a slightly negative correlation with 1849 steam engines in mining per capita.

Another resource relevant in particular for the textile industry is wool, which we can proxy by the number of sheep in 1816. More generally, counts of different livestock in 1816 provide measures of agricultural development. However, such agricultural measures at the time may also proxy for a lack of development in terms of craftsmen, commerce, and other businesses. The latter aspect can also be captured by the share of farm laborers in the county population, available for 1819. The number of sheep per capita is unrelated to subsequent industrialization, whereas agricultural employment is negatively associated with subsequent industrialization (column (4)). But again, neither affects the education estimate. As a measure of dependent labor, the share of servants in the total county population also enters the model negatively but leaves

14 Similarly, the 1882 census provides a sub-category for manufacturing industries in mining, steel-mill operations, and salt production. Our results below are robust to excluding workers in this sub-sector from our manufacturing variable, and also to including the sub-sector as an additional control. 
the education result unaffected (not shown). A host of additional livestock counts, such as the number of cattle, horses, pigs, oxen, bulls, and foals, are either insignificantly or negatively associated with subsequent industrialization, and none affects the education result (not shown).

Finally, public infrastructure in existence before the industrialization may have facilitated the adoption of industrial technologies. We obtained data on the number of public utility buildings in 1821. To account for transport infrastructure, we also obtained an indicator on whether paved interregional streets existed in the county in 1815, as well as a measure of the tonnage capacity of transport ships in 1819. These measures may also capture differential connectedness, such as trade access, of Prussian counties with the outside world, especially Britain. As is evident from column (7), none of these is significantly positively associated with later industrialization, and none affects the qualitative education result. The same is true when the length of navigable rivers is added as an alternative measure of transport infrastructure (not shown).

The size of the estimated effect of education on industrialization actually increases to 0.052 relative to the OLS estimate of 0.031 (or 0.027 in a specification equivalent to column (7) of Table 4, not shown), once the whole set of indicators of pre-industrial development is added to the model. Rather than mitigating the estimated effect of education on industrialization, accounting for pre-industrial development actually strengthens the education result. This suggests that either the downward bias of a negative effect of industrialization on the demand for education dominates in the first phase of industrialization, or there is measurement error in the 1849 education variable that is remedied when instrumenting it by 1816 education.

Results of this preferred specification for the three industrial sub-sectors (columns (8) to (10)) show strong evidence for a positive effect of education on industrial development outside the metal and textile industries during the first phase of the Industrial Revolution until 1849, and some evidence for a positive effect in the metal industry. By contrast, there is no evidence that education positively affected industrialization in the textile industry.

As should be expected, among the pre-industrial development controls, looms in 1819 are particularly relevant in predicting industrialization in textiles, whereas steam engines in 1849 mining are particularly relevant in predicting industrialization in metals. Having a paved street in 1815 is particularly relevant in predicting industrialization outside these two specific industries, in line with the view that connectedness with the outside world, and in particular with Britain, may have been particularly relevant in non-traditional sectors. 


\section{The Second Phase of Industrialization}

Table 5 reports results of the model with pre-industrial development controls for the second phase of industrialization. Both OLS and IV estimates show a significant positive effect of literacy (measured in 1871) on total manufacturing employment in 1882. Again, 1816 school enrollment is a strong instrument for 1871 literacy in the first stage of the IV specification. The significant positive impact of education on industrialization is evident both in the industries outside metals and textiles and in the metal industry, but again not in textiles. It seems that by focusing on the textile industry, a lot of the existing literature may have missed the important role of education in the Industrial Revolution (see Section $\mathrm{V}$ for further discussion).

We can now turn to a discussion of the size of the estimated effect of education in the two phases. Our estimates suggest that in 1849, a 10 percentage point (p.p.) higher school enrollment rate led to 0.5 p.p. higher per-capita factory employment (equivalent to 0.9 p.p. higher perworker factory employment, see Section IV.E below). In the 1870s/80s, a 10 p.p. higher literacy rate led to 1.0 p.p. higher per-capita manufacturing employment (or 2.6 p.p. higher per-worker manufacturing employment). This may not seem very much, as it suggests that only one in four additionally educated workers went into industrial production in 1882, and only one in ten in 1849. The majority of workers with basic education still worked outside the industrial sector.

However, the estimated effect sizes are very substantial when viewed against the average level of industrialization reached at the time. In 1849, average per-capita factory employment across the Prussian counties was only $1.8 \%$ (ranging from $0.4 \%$ to $8.5 \%$ from the $1^{\text {st }}$ to the $99^{\text {th }}$ percentile of counties). A simple linear simulation would suggest that if all Prussian counties would have had only the education level of the $1^{\text {st }}$-percentile county ( $46 \%$ rather than the actual average $80 \%$ school enrollment rate), then per-capita factory employment would have been 1.8 p.p. lower. In other words, in this thought experiment, there would virtually not have been any industrial production in Prussia if it had had such a low level of education.

Similarly, if all Prussian counties would have had only a literacy rate of $46 \%$ in 1871 (the $1^{\text {st }}$ percentile county) rather than the actual average 84\%, then 1882 per-capita manufacturing employment would have been 3.8 p.p. lower. This amounts to a third of actual total per-capita manufacturing employment of $11.6 \%$. In sum, the variation in education that existed across Prussian counties can account for a substantial part of Prussian industrialization. 
The estimates of Table 5 do not control for the level of industrialization already reached by the end of the first phase of the Industrial Revolution. To depict the effect of education on the progress of industrialization during the second phase, between 1849 and 1882, Table 6 adds the level of industrialization reached in 1849 as a control variable. Given this control, we can add 1849 enrollment as a second instrument in addition to 1816 enrollment in this specification. The Sargan tests do not reject the validity of the over-identification restrictions (although they come close in textiles, where we do not find an education effect). In all three sectors, the 1849 share of factory workers in the sector enters significantly and strongly in predicting the 1882 employment share in the sector. Still, the significant positive impact of education on industrialization outside textiles remains, albeit slightly (but not statistically significantly) smaller. Thus, education affected industrialization not only during the first phase of the Industrial Revolution, but also the additional progress of industrialization during the second phase.

\section{Distance to Wittenberg as an Alternative Instrument}

Distance to Wittenberg, suggested as an alternative instrument for the spread of education within Prussia because of Luther's urge for Bible reading, is indeed a strong instrument for our education measures both in 1849 and 1871 (Table 7). The specification confirms our previous results: Education has a significant positive effect on total industrialization during both phases of the Industrial Revolution, which is strongly borne by industrialization outside metals and textiles.

In the metal industry, the effect is again marginally significant in the first phase and strongly significant in the second phase. By contrast, the effect is again insignificant in the textile industry (not shown) in the first phase (it gets significantly positive in the second phase in some but not all specifications). The coefficient for industries other than metals and textiles in the second phase is substantially larger with the Wittenberg instrument than in the previous specifications. ${ }^{15}$

\section{E. Additional Robustness Tests}

To test whether Protestantism had a significant independent effect on industrialization, we can add the share of Protestants in a county to the model. Such a model is reported in columns (1) and (5) of Table 8. In line with Becker and Woessmann (2009), the Protestant share is not

\footnotetext{
${ }^{15}$ The difference in point estimates may result from different complier sub-populations being affected by the different instruments. Results are similar when we apply both instruments together (not shown).
} 
significantly associated with industrialization once the effect of education is controlled for. The next columns add the share of Jews, which is negatively associated with industrialization. This may depict the traditional role of the Jewish community in merchant occupations, outside industry. The effect of education is robust to the inclusion of the religious indicators.

To test whether it mattered how long a county had been part of the common institutional and legal framework of Prussia, columns (3) and (8) add the year when a county was annexed by Prussia. While later annexations tended to be more likely to industrialize during the second phase, accounting for this actually increases the estimated effect of education.

The county of Iserlohn, which was well-known as a leading industrial center worldwide in the first half of the $19^{\text {th }}$ century for its large metalworking factories (evidenced, for example, by an Iserlohn-produced coat of mail on display in the Tower of London), is a significant outlier in metal factories during the first phase. In Iserlohn, $16.5 \%$ of the population worked in metal factories in 1849, whereas the next-biggest share in any other Prussian county was 5.9\%. The qualitative results on the impact of education on industrialization are unaffected when estimating the models without Iserlohn to ensure that results are not driven by this outlier (not shown).

To test whether our estimates are affected by local migration, we compute the average of the education variables for each county and its neighboring counties (defined as sharing a border). In some cases, children from one county might have enrolled in school in a neighboring county, so that this average might reduce measurement error in the education variables. The average education level also addresses the fact that the industrial labor force might have been recruited on a broader regional market, capturing regional migration in search of employment. As the results reported in columns (4) and (9) of Table 8 show, results are robust when using the regional average of the education variables. The point estimates even increase in size, suggesting that regional migration for school or work might indeed attenuate the previous findings.

As additional tests for migration, we can add indicators of the shares of the county population that were born in the respective municipality and that are of Prussian origin, both available for 1871 (not shown). The estimated effect of education is robust to the inclusion of these migration indicators and even increases in size, again suggesting that if anything, migration biases the estimated effect of home-county education downwards.

All models so far measure industrial employment as a share of the total county population, which is unaffected by possible endogeneity of total employment. Columns (5) and (10) of Table 
8 instead use the share of industrial employment in the occupied labor force as the dependent variable. The results suggest that a 10 percentage point (p.p.) increase in our education measures resulted in an 1849 share of factory workers in the labor force that was 0.9 p.p. higher, and in an 1882 share of manufacturing workers in the labor force that was 2.6 p.p. higher. Results are very similar when using the population aged older than 16 (available in 1849) or the population aged 20 to 69 (available in 1882) as the denominator instead of the occupied labor force.

Results reported so far refer to basic education, measured by enrollment rates in elementary and middle schools and by literacy rates. On average, enrollment rates in upper-secondary schools did not surpass 5 percent throughout our $19^{\text {th }}$-century data, and a maximum of eight universities existed on Prussian ground. When we add upper-secondary enrollment rates and universities to our models, they do not enter significantly (mostly with a negative point estimate) and do not change the significant positive effects of basic education (not shown). This suggests that the basic follower mechanisms highlighted in Section I which stress the role of basic education for technology diffusion, rather than higher-skill or entrepreneurial channels, were most relevant for relative regional industrialization in Prussia in the $19^{\text {th }}$ century.

Finally, Table 9 reports a set of geographical robustness tests. As is evident in Figure 1, Prussia in 1849 was divided into two separated parts - the Rhineland and Westphalia to the West and the other provinces to the East. To ensure that results are not driven by this separation, columns (1) and (5) add a dummy for the Western parts. Results are qualitatively unaffected, and the Western dummy is insignificant. However, it enters significantly negative in the estimation for industries outside metals and textiles and significantly positive for the metal industry (not shown), in line with the coal-driven industrialization in the Ruhr area. Still, the qualitative results on the effect of education remain unaffected also in the two sub-sectors.

To control for possible differences in counties with Slavic languages, columns (2) and (6) add an indicator for counties located in Poland today. While the indicator enters significantly negatively (although not outside metals and textiles, not shown), the qualitative results for the education effect remain the same. The same qualitative results are also obtained when including an indicator for the three predominantly Polish-speaking provinces Prussia, Poznan, and Silesia.

As additional geographical robustness tests, columns (3) and (7) augment the model by distance to Berlin as the Prussian capital, distance to the closest province capital, and distance to London. The latter measure may capture effects of the geographical distance to Britain, where 
the new industrial technologies originated. As expected, industrialization is lower, the further away a county is from London and from Berlin, and the closer it is to a province capital. However, none of these controls affects the qualitative result on the role of education in industrialization. The specification in columns (4) and (8) even adds a full geographical grid of latitude and longitude, again leaving the education result unaffected.

\section{Interpretation in Relation to Existing British Evidence}

The reported results constitute a substantial change in the empirical assessment of the historical role of education in the transition to modern industrial growth. The literature so far has not found a similar education effect during the first phase of the Industrial Revolution in Britain (cf. Mitch 1999 for an encompassing review). We propose four likely reasons for the differing findings, all of which - while necessarily speculative - seem to us to carry some truth. The four arguments are data availability, specifics of the textile sector, differences between industrial leader and follower countries, and Humboldt's educational ideal.

The first and most likely cause for a lack of evidence in Britain is the lack of relevant data needed for a thorough test of the role of education in industrialization. Absence of proof is not proof of absence. The data situation in Britain is very different from Prussia. Industrialization in Britain started earlier, in the second half of the $18^{\text {th }}$ century. But the first national schooling survey was in 1818 (Mitch 1999), and the first centrally administered census covering all household members was not conducted until 1841. As a consequence, British studies have to rely mostly on Parish registers (often drawing on poor proxies for education like signatures in marriage registers), which by necessity remain eclectic and limited in comparability compared to the representative data from full national censuses available in Prussia.

The main evidence underlying the argument of a limited role of education in British industrialization is that the level of education stagnated during the first phase of the Industrial Revolution in England and that its use actually declined in some leading sectors. Even though both findings are highly contested, they surely contain some truth (Mitch 1999). However, this is no evidence that education was not important for the emergence of industrial production and for development during the Industrial Revolution more generally (cf. Laqueur 1974 for a similar argument). It is clearly possible that education was relevant for the emergence and adoption of British industrialization in the late $18^{\text {th }}$ century, while the demand for education then declined 
during the first phase of industrialization. Education may be required for the management, scientific, and engineering tasks to decipher, understand, and adopt a new technology and discover and master the tricks necessary in production. But once adopted, the technology gets standard, the production task ordinary, and education less important in production. To test the relevance of education for British industrialization, one would thus need cross-sectional data on education before the emergence of industrial technologies. The role of pre-existing education for industrialization in Britain has not been tested, and it seems that the required data do not exist.

The data argument also contains a deeper point. British evidence - including the growthaccounting analysis by Crafts (1995) - tends to focus on changes in education, as does Lundgreen's (1976) Prussian aggregate-level analysis for 1864-1911. However, if the theoretical framework outlined in Section I is correct, which models the role of education not as a standard factor of production but as facilitating technological diffusion, it is not the change in education that is relevant for industrialization, but the level of education (cf. Krueger and Lindahl 2001).

Second, the focus of the existing Industrial-Revolution literature on cotton textiles may be misleading (cf. Komlos 2000). The bulk of British evidence on the role of education is for the textile sector, and it is there that education levels may actually have declined (Mitch 1999). According to our Prussian findings, the textile sector may be very different from most other industries in terms of the role of education. A possible reason for this is that innovations were much more incremental and less disruptive in textiles than in other industries. New technologies in textiles built closely on previously available technologies. By contrast, many other industries only emerged during the Industrial Revolution, or at least had their processes transformed much more radically. According to our theoretical framework, the role of education was much more limited where the need to adapt to radical change was less intensive. Because textile production existed before industrial times as a substantial sector, industrial development in textiles may have exhibited substantial path dependence (as evidenced above by the effect of 1819 looms on 1849 textile factories). This may have been aggravated by the existence of substantial sunk costs (as suggested by the fact evident in our archive data that hand-driven looms existed in the same factories next to mechanical ones for a long time; cf. also Henning 1995).

The incremental development also made applied types of sector-specific knowledge, more easily acquired through informal instruction on the job, more relevant in textiles than general types of knowledge acquired through formal education (cf. Crafts 1995, 1996 and Mitch 1999 on 
the substantial role of informal learning in Britain). Another possibility is that child labor was more prevalent in textiles than in other industries, reducing the estimated effect of education. Also, establishing industrial factories in textiles, where they displaced existing non-factory production, created more social unrest than in completely new industries (Weber 2003, p. 326), possibly inducing textile entrepreneurs to evade educated regions. Textile industrialization in Prussia was "very slow" and "extended over a whole century", so that it was "not possible to speak of a take-off” in the German textile industry (Henning 1995, pp. 139, 144). In Prussia, an additional reason for this may have been cheap import competition (amplified by the fact that Prussia could not grow cotton and had no colonies at the time). As a consequence, in contrast to Britain, textiles were not a leading sector of industrialization in Prussia (Henning 1995).

While the first two points imply that education may have had the same effect in each sector in Britain as in Prussia, the remaining two points suggest a larger education role in Prussia.

The third point is the core argument of the leader-follower model outlined above, where the role of education emerges from the need to adjust to exogenously determined changes. This makes education particularly relevant in an imitating country like Prussia at the beginning of its industrialization. By contrast, the factors determining the truly innovative development in the industrial leader country Britain may be different (see Section I). As the innovation literature duly points out, much innovative activity has a lot of chance to it (cf. Crafts 1995 for an application to the Industrial Revolution), and the skills needed for innovation may (or may not) be quite different and less dependent on formal education than the skills needed for imitation. Of course, the application stage in some regions and factories in Britain may not have been too different from the catch-up phase in Prussia. But again, less formal forms of communication and instruction were available inside Britain that were not available for people outside Britain who had less interaction with the new technologies and even spoke a different language.

The fourth point refers to the type of education most relevant for the ability to adjust to change (cf. Appendix B). Here, the reforms of the Prussian education system famously initiated by Wilhelm von Humboldt as Prussian Minister of Education in 1808 receive particular relevance. As Jeismann (1987, p. 5) points out with regard to the 1806-1813 period of Napoleonic reign in Prussia, “The 'period of the French' was the incubation period of the German education system of the $19^{\text {th }}$ century.” The education reforms had a key function in the more general Prussian reforms at the time, which presupposed a type of citizen able to act as 
self-responsible human being. Humboldt managed to initiate fundamental reforms of curricula, teaching methods, teacher education, and auditing in the school system. The reforms were rather pragmatic, and many sources report that as early as 1811, they were successfully implemented even in distant regions and had visible consequences in schools (cf. Schmitt 2001).

The reforms advanced Humboldt's humanistic educational ideal of an encompassing general education which aimed to implant the ability of rational thinking in the broad masses. The general knowledge of the Humboldt type may be particularly relevant to foster the ability to deal with economic disequilibria. According to the Handbook of German Education History (Jeismann 1987, p. 13), the expansion of the education system fostered industrial modernization with lasting effect, particularly "through an education, extending by and by into the broad masses, to ways of thinking that were oriented ultimately at scientific rationality, by familiarization with intellectual rigor, accuracy, and verifiability of the results of one's own endeavors." Although not focusing on specific technical abilities, the Prussian education system may thus have fostered the ability to learn how to learn, which provides the basis for independent study in a synergistic learning process (cf. Cunha and Heckman 2007 for a modern emphasis). Compared to all other countries, Prussian schools may have taught a curriculum that was of particular use in adopting new technologies (cf. Easterlin 1981 for an example that a rationalistic education was not the uniform rule at the time). Somewhat ironically, although the Humboldt reforms were partly aimed against an excessively utilitarian type of education that conveyed just the skills necessary for a specific occupation, they may actually have imparted exactly the type of skills necessary for an economy in which adaptation to rapid change was asked for.

\section{Conclusion}

This paper has analyzed the role of education in industrial catch-up across Prussian counties over the $19^{\text {th }}$ century. Although historical commentary sometimes argues that education played a prominent role in the emerging Industrial Revolution, positive evidence on this is virtually nonexistent. Sound empirical evidence, mostly restricted to textile industries in the industrial leader Britain, rather suggests no role for education, at least during the first phase of industrialization.

By contrast, we find that education had a significant effect on aggregate industrialization in both phases of the Industrial Revolution in Prussia. The aggregate result conceals important sectoral differences, though. In fact, there was no such effect in the textile industry in either 
phase of industrialization, possibly due to substantial path dependence that made change in this sector slow and incremental rather than disruptive, in particular in Prussia. But the effect of education is substantial during both phases of industrialization in the bulk of industry, outside textiles. Industrial development in the non-textile sectors, which experienced more radical change or even evolved all new, depended on the availability of an educated population that was earlier aware of the productive potential of new technologies and more capable of adjusting to changed situations. Some regions lacked these skills necessary to adopt the new industrial technologies from and catch up to Britain. Quantitatively, the variation in education levels that existed across Prussian counties can account for a substantial part of Prussian industrialization. A simple linear simulation suggests that if all Prussian counties had had only the education level of the $1^{\text {st }}$-percentile county, there would not have been any noteworthy industrialization in Prussia by 1849 and only about one third of the actual industrialization in 1882 .

Our empirical identification builds on an "historical experiment": The Industrial Revolution came as an exogenous shock to Prussia once the fundamental institutional reforms of the early 1800s had unleashed the potential for economic change. We estimate what happens if different regions of the same country with different levels of pre-existent education are shocked with new industrial technologies from outside that did not exist before. This is the classical situation modeled by leader-follower models of technological catch-up. The general basic education implemented by Humboldt in Prussia, which aimed at creating independent rational thinking and self-responsible action among the broad masses, proved particularly relevant in this setting which asked for the ability to deal with change. In line with this, we find significant effects for basic education, but not for upper-secondary and higher education.

Our econometric model uses education levels that predate industrialization in Prussia (1816) as instruments for education levels observed during the first (1849) and second (1882) phase of industrialization, made possible by our unique census-based database covering all 334 Prussian counties over the $19^{\text {th }}$ century. By exploiting this panel structure, we are able to use only that part of the educational variation during industrial times that can be traced back to variation preexisting industrial times, stemming from historical peculiarities. This approach rules out the most obvious sources of endogeneity in the education-industrialization nexus. The 1816 level of education is not affected by changes in demand that might have been brought about by industrialization itself, as modeled in most unified growth theories (cf. Galor 2005). 
Because our approach exploits variation within one country across counties which share a common set of basic institutional, legal, cultural, and climatic features, we can rule out substantial biases from correlations of 1816 education levels with institutional and geographic factors that are related to subsequent industrialization. To further rule out biases from the possibility that industrialization may have been facilitated by the level of pre-industrial development (possibly correlated with pre-industrial education), we compiled a rich set of preindustrial development indicators, including measures of pre- and proto-industrial technologies, urbanization, agricultural development, natural resources, and infrastructure. Although several of these indicators are indeed significantly related to subsequent industrialization, none of them affects the estimated effect of education on industrialization.

As another approach to identification, we exploit the fact that the $16^{\text {th }}$-century concentric spread of Protestantism in Prussia gave rise to educational variation, owing to Luther's urge that each Christian should be able to read the Bible (Becker and Woessmann 2009). Using distance to Wittenberg as an alternative instrument for education, we corroborate our findings.

Our results suggest that without her internationally outstanding education system before the onset of the Industrial Revolution, Prussia would probably not have been able to be a successful industrial follower, to the extent that she managed to take over technological leadership from Britain in many sectors by the end of the $19^{\text {th }}$ century (cf. Landes 1969). In line with catch-up models in the spirit of Nelson and Phelps (1966), technological diffusion depended strongly on investments in human capital. Economic history may in fact be more in line with this type of growth models than was previously thought. In terms of the adoption of new technologies (rather than their subsequent use in production when they have become standard), human skills may have been a complement to new technologies not only starting with the early $20^{\text {th }}$ century, as shown by Goldin and Katz (1998), but even earlier. Education played a much larger role both in the first and the second phase of the Industrial Revolution outside Britain than most assessments based on the current state of empirical evidence seemed to suggest. The relative importance of the different reasons for the differing findings between Prussia and Britain - inferior British data, textile-sector specifics, leader-follower differences, and Humboldt's ideals in Prussian education - open a range of interesting questions for future research. 


\section{References}

Abramovitz, Moses (1986). Catching Up, Forging Ahead, and Falling Behind. Journal of Economic History 46 (2): 385-406.

Acemoglu, Daron, Philippe Aghion, Fabrizio Zilibotti (2006). Distance to Frontier, Selection, and Economic Growth. Journal of the European Economic Association 4 (1): 37-74.

Acemoglu, Daron, Davide Cantoni, Simon Johnson, James A. Robinson (2008). From Ancien Régime to Capitalism: The Spread of the French Revolution as a Natural Experiment. Harvard University, Mimeo. Forthcoming in: Jared Diamond, James A. Robinson (eds.), Natural Experiments of History. Cambridge, MA: Harvard University Press.

Acemoglu, Daron, Simon Johnson, James A. Robinson (2002). Reversal of Fortune: Geography and Institutions in the Making of the Modern World Income Distribution. Quarterly Journal of Economics 117 (4): 1231-1294.

A'Hearn, Brian (1998). Institutions, Externalities, and Economic Growth in Southern Italy: Evidence from the Cotton Textile Industry,1861-1914. Economic History Review 51 (4): 734762.

Allen, Robert C. (2003). Progress and Poverty in Early Modern Europe. Economic History Review 56 (3): 403-443.

Allen, Robert C. (2009). The British Industrial Revolution in Global Perspective. Cambridge: Cambridge University Press.

Bairoch, Paul (1988). Cities and Economic Development: From the Dawn of History to the Present. Chicago, IL: University of Chicago Press.

Becker, Sascha O., Ludger Woessmann (2009). Was Weber Wrong? A Human Capital Theory of Protestant Economic History. Quarterly Journal of Economics 124 (2): 531-596.

Benhabib, Jess, Mark M. Spiegel (2005). Human Capital and Technology Diffusion. In: Philippe Aghion, Steven N. Durlauf (eds.), Handbook of Economic Growth, Volume 1A, pp. 935-966. Amsterdam: North Holland.

Bessen, James (2003). Technology and Learning by Factory Workers: The Stretch-Out at Lowell, 1842. Journal of Economic History 63 (1): 33-64.

Blanchard, Olivier, Justin Wolfers (2000). The Role of Shocks and Institutions in the Rise of European Unemployment: The Aggregate Evidence. Economic Journal 110 (462): C1-C33.

Borchardt, Knut (1973). Germany 1700-1914. In: Carlo M. Cipolla (ed.), The Fontana Economic History of Europe, Vol. 4: The Emergence of Industrial Societies, Part I, pp. 76-160. London: Collins.

Clark, Gregory (2005). The Condition of the Working Class in England, 1209-2004. Journal of Political Economy 113 (6): 1307-1340.

Clark, Gregory (2007). A Farewell to Alms: A Brief Economic History of the World. Princeton: Princeton University Press.

Crafts, Nicholas F.R. (1977). Industrial Revolution in England and France: Some Thoughts on the Question, “Why was England First?” Economic History Review 30 (3): 429-441.

Crafts, Nicholas F.R. (1995). Exogenous or Endogenous Growth? The Industrial Revolution Reconsidered. Journal of Economic History 55 (4): 745-772.

Crafts, Nicholas F.R. (1996). The First Industrial Revolution: A Guided Tour for Growth Economists. American Economic Review 86 (2): 197-201.

Cunha, Flavio, James J. Heckman (2007). The Technology of Skill Formation. American Economic Review 97 (2): 31-47. 
Easterlin, Richard A. (1981). Why Isn't the Whole World Developed? Journal of Economic History 41 (1): 1-19.

Galor, Oded (2005). From Stagnation to Growth: Unified Growth Theory. In: Philippe Aghion, Steven N. Durlauf (eds.), Handbook of Economic Growth, Volume 1A, pp. 171-293. Amsterdam: North Holland.

Galor, Oded, Omer Moav (2006). Das Human-Kapital: A Theory of the Demise of the Class Structure. Review of Economic Studies 73 (1): 85-117.

Galor, Oded, Omer Moav, Dietrich Vollrath (2009). Inequality in Land Ownership, the Emergence of Human Capital Promoting Institutions, and the Great Divergence. Review of Economic Studies 76 (1): 143-179.

Gerschenkron, Alexander (1962). Economic Backwardness in Historical Perspective. Cambridge, MA: Belknap Press.

Goldin, Claudia, Lawrence F. Katz (1998). The Origins of Technology-Skill Complementarity. Quarterly Journal of Economics 113 (3): 693-732.

Hahn, Hans-Werner (2005). Die Industrielle Revolution in Deutschland. $2^{\text {nd }}$ edition. München: Oldenbourg.

Hanushek, Eric A., Ludger Woessmann (2008). The Role of Cognitive Skills in Economic Development. Journal of Economic Literature 46 (3): 607-608.

Henning, Friedrich-Wilhelm (1995). Die Industrialisierung in Deutschland 1800 bis 1914. $9^{\text {th }}$ edition. Wirtschafts- und Sozialgeschichte, Band 2. Paderborn: Ferdinand Schöningh.

Hoffmann, Walther G. (1963). The Take-off in Germany. In: Walt W. Rostow (ed.), The Economics of Take-off into Sustained Growth. London: Macmillan.

Hohorst, Gerd (1980). Regionale Entwicklungsunterschiede im Industrialisierungsprozeß Preußens - ein auf Ungleichgewichten basierendes Entwicklungsmodell. In: Sidney Pollard (ed.), Region and Industrialisation: Studies on the Role of the Region in the Economic History of the Last Two Centuries, pp. 215-238. Göttingen: Vandenhoeck \& Ruprecht.

Jeismann, Karl-Ernst (1987). Zur Bedeutung der „Bildung“ im 19. Jahrhundert. In: Karl-Ernst Jeismann, Peter Lundgreen, (eds.), Handbuch der deutschen Bildungsgeschichte, Band III, 1800-1870: Von der Neuordnung Deutschlands bis zur Gründung des Deutschen Reiches, pp. 1-21. München: Verlag C.H. Beck.

Kiesewetter, Hubert (2004). Industrielle Revolution in Deutschland: Regionen als Wachstumsmotoren. Stuttgart: Steiner Verlag.

Kindleberger, Charles P. (1995). Technological Diffusion: European Experience to 1850. Journal of Evolutionary Economics 5 (3): 229-242.

Komlos, John (2000). The Industrial Revolution as the Escape from the Malthusian Trap. Journal of European Economic History 29 (2-3): 307-331.

Königliches Handelsamt zu Berlin (1847). Ueber den Chausseebau in Preussen. Handels-Archiv 1847 (1): 93-109.

Krueger, Alan B., Mikael Lindahl (2001). Education for Growth: Why and For Whom? Journal of Economic Literature 39 (4): 1101-1136.

Landes, David S. (1969). The Unbound Prometheus: Technological Change and Industrial Development in Western Europe from 1750 to the Present. New York, NY: Cambridge University Press.

Landes, David S. (1998). The Wealth and Poverty of Nations: Why Some Countries Are So Rich and Some So Poor. New York: W.W. Norton. 
Laqueur, Thomas W. (1974). Debate: Literacy and Social Mobility in the Industrial Revolution in England. Past and Present (64): 96-107.

Lenoir, Timothy (1998). Revolution from Above: The Role of the State in Creating the German Research System, 1810-1910. American Economic Review 88 (2): 22-27.

Lindert, Peter H. (2004). Growing Public: Social Spending and Economic Growth since the Eighteenth Century. Two volumes. Cambridge: Cambridge University Press.

Lundgren, Peter (1973). Bildung und Wirtschaftswachstum im Industrialisierungsprozeß des 19. Jahrhunderts: Methodische Ansätze, empirische Studien und internationale Vergleiche. Berlin: Colloquium Verlag.

Lundgren, Peter (1976). Educational Expansion and Economic Growth in Nineteenth-Century Germany: A Quantitative Study. In: Lawrence Stone (ed.), Schooling and Society: Studies in the History of Education, pp. 20-66. Baltimore, Maryland: Johns Hopkins University Press.

Mitch, David (1993). The Role of Human Capital in the First Industrial Revolution. In: Joel Mokyr (ed.), The British Industrial Revolution: An Economic Perspective, pp. 267-307. Boulder: Westview.

Mitch, David (1999). The Role of Education and Skill in the British Industrial Revolution. In: Joel Mokyr (ed.), The British Industrial Revolution: An Economic Perspective, $2^{\text {nd }}$ edition, pp. 241-279. Boulder: Westview.

Mokyr, Joel (1990). The Lever of Riches. Oxford: Oxford University Press.

Mokyr, Joel (1999). The New Economic History and the Industrial Revolution. In: Joel Mokyr (ed.), The British Industrial Revolution: An Economic Perspective, $2^{\text {nd }}$ edition, pp. 1-127. Boulder: Westview.

Nagel, Rolf (2004). Lehrer, Schüler und Schulen im preußischen Gelderland von 1814 bis 1818. In: Karl Keller, Rolf Nagel, Peter Stenmans (eds.), Beiträge zur Kirchen- und Schulgeschichte des Gelderlandes, pp. 525-579. Geldern: Verlag des Historischen Vereins für Geldern und Umgegend.

Nelson, Richard R., Edmund S. Phelps (1966). Investment in Humans, Technological Diffusion, and Economic Growth. American Economic Review 56 (2): 69-75.

O’Rourke, Kevin H., Jeffrey G. Williamson (1996). Education, Globalization and Catch-Up: Scandinavia in the Swedish Mirror. Scandinavian Economic History Review 43 (3): 287-309.

Pierenkemper, Toni, Richard H. Tilly (2004). The German Economy during the Nineteenth Century. New York: Berghahn Books.

Pollard, Sidney (1981). Peaceful Conquest: The Industrialization of Europe 1760-1970. Oxford: Oxford University Press.

Radkau, Joachim (2008). Technik in Deutschland: Vom 18. Jahrhundert bis heute. Frankfurt am Main: Campus Verlag.

Rosés, Joan R. (1998). Measuring the Contribution of Human Capital to the Development of the Catalan Factory System (1830-61). European Review of Economic History 2 (1): 25-48.

Sandberg, Lars G. (1979). The Case of the Impoverished Sophisticate: Human Capital and Swedish Economic Growth before World War I. Journal of Economic History 39 (1): 225-241.

Sanderson, Michael (1972). Literacy and Social Mobility in the Industrial Revolution in England. Past and Present (56): 75-104.

Schmitt, Hanno (2001). Selbstorganisation, Bildungsfähigkeit und Zwang: Die Reform der Elementarschulen in der Provinz Brandenburg 1809-1816. In: Hans Jürgen Apel, Heidemarie Kemnitz, Uwe Sandfuchs (eds.), Das öffentliche Bildungswesen: Historische Entwicklung, gesellschaftliche Funktionen, pädagogischer Streit. Bad Heilbrunn: Julius Klinkhardt. 
Schofield, Roger S. (1973). Dimensions of Illiteracy, 1750-1850. Explorations in Economic History 10 (4): 437-454.

Schönemann, Bernd (1993). Die Bildungsinstitutionen in der frühen Neuzeit. In: Franz-Josef Jakobi (ed.), Geschichte der Stadt Münster, vol. 1, pp. 683-733. Münster: Aschendorff.

Schultz, Theodore W. (1975). The Value of the Ability to Deal with Disequilibria. Journal of Economic Literature 13 (3): 827-846.

Taylor, Alan M. (1999). Sources of Convergence in the Late Nineteenth Century. European Economic Review 43 (9): 1621-1645.

Tilly, Richard H. (1996). German Industrialization. In: Mikuláš Teich, Roy Porter (eds.), The Industrial Revolution in National Context: Europe and the USA, pp. 95-125. Cambridge: Cambridge University Press.

Vandenbussche, Jerome, Philippe Aghion, Costas Meghir (2006). Growth, Distance to Frontier and Composition of Human Capital. Journal of Economic Growth 11 (2): 97-127.

Voigtländer, Nico, Hans-Joachim Voth (2006). Why England? Demographic Factors, Structural Change and Physical Capital Accumulation during the Industrial Revolution. Journal of Economic Growth 11 (4): 319-361.

von Tunzelmann, G. Nick (2000). Technology Generation, Technology Use and Economic Growth. European Review of Economic History 4 (2): 121-146.

Weber, Wolfhard (2003). Science, Technology, and Society in Germany from 1800 to the Present. In: Sheilagh Ogilvie, Richard Overy (eds.), Germany: A New Social and Economic History, vol. 3: Since 1800, pp. 320-354. New York, NY: Oxford University Press.

Welch, Finis (1970). Education in Production. Journal of Political Economy 78 (1): 35-59.

West, E.G. (1978). Literacy and the Industrial Revolution. Economic History Review 31 (3): 369383. 


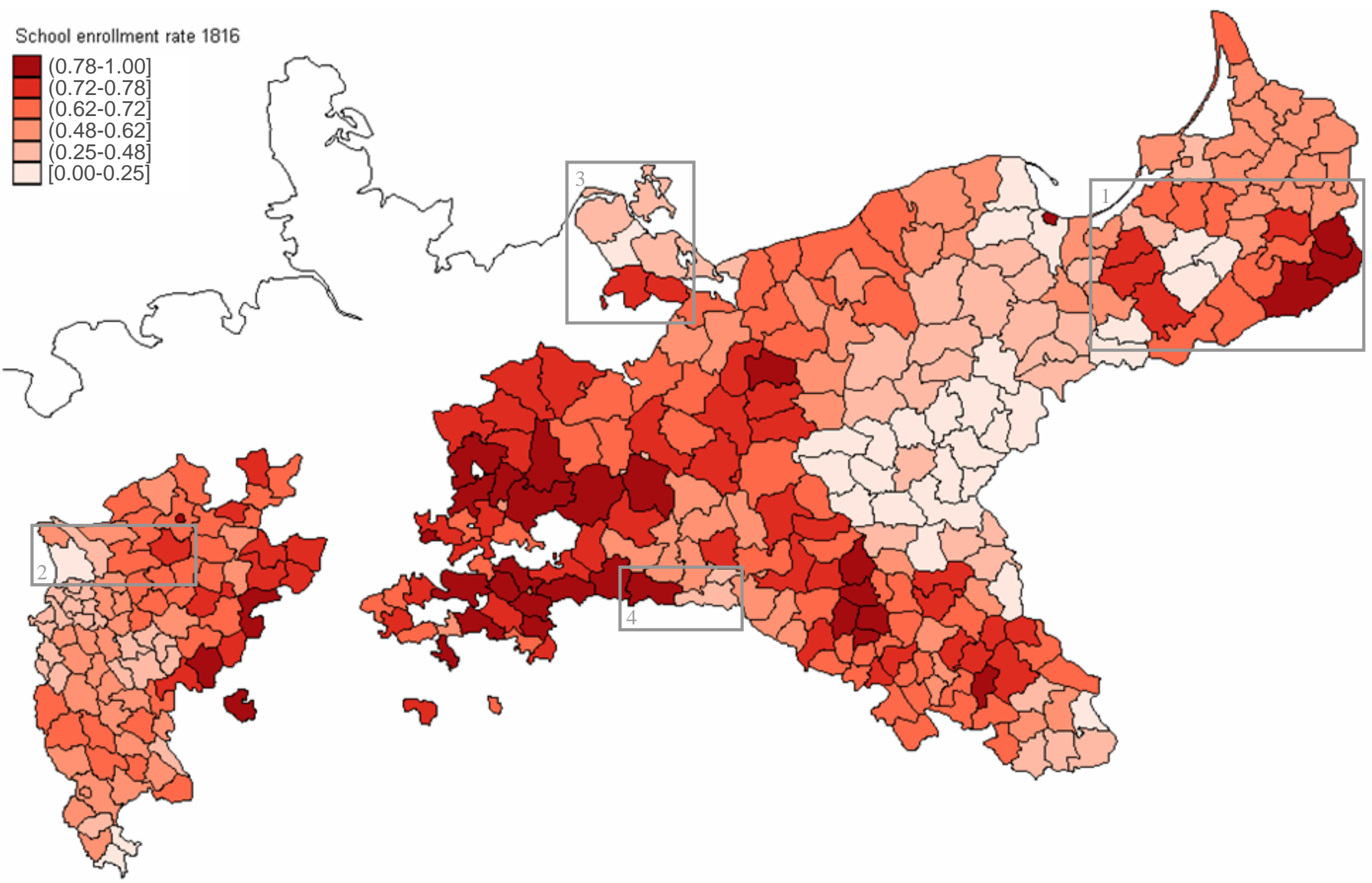

Notes: County-level depiction based on the 1816 Population Census. Enrollment rates refer to enrollment in elementary and middle schools divided by the population aged 6 to 14 . The delimiters correspond roughly to the $10^{\text {th }}, 25^{\text {th }}, 50^{\text {th }}, 75^{\text {th }}$, and $90^{\text {th }}$ percentile of the variable. See Appendix A for data details. The four rectangles point out the four example regions referred to in the text. 
TABLe 1: Descriptive STATISTICS

\begin{tabular}{|c|c|c|c|c|}
\hline & $\begin{array}{l}\text { Mean } \\
\text { (1) }\end{array}$ & $\begin{array}{l}\text { Std. dev. } \\
\text { (2) }\end{array}$ & $\begin{array}{l}\text { Min } \\
(3)\end{array}$ & $\begin{array}{c}\text { Max } \\
\text { (4) }\end{array}$ \\
\hline \multicolumn{5}{|l|}{ Education measures: } \\
\hline School enrollment rate 1816 & 0.577 & 0.201 & 0.027 & 0.954 \\
\hline School enrollment rate 1849 & 0.801 & 0.117 & 0.334 & 0.989 \\
\hline Literacy rate 1871 & 0.839 & 0.136 & 0.361 & 0.985 \\
\hline \multicolumn{5}{|l|}{ Share of factory workers in total population 1849: } \\
\hline All factories & 0.018 & 0.017 & 0.004 & 0.185 \\
\hline All factories except metals and textiles & 0.009 & 0.008 & 0.002 & 0.072 \\
\hline Metal factories & 0.006 & 0.011 & 0.000 & 0.165 \\
\hline Textile factories & 0.003 & 0.007 & 0.000 & 0.070 \\
\hline Share of all factory workers in occupied labor force & 0.028 & 0.032 & 0.003 & 0.353 \\
\hline \multicolumn{5}{|l|}{ Share of manufacturing workers in total population 1882: } \\
\hline All manufacturing & 0.116 & 0.058 & 0.022 & 0.292 \\
\hline All manufacturing except metals and textiles & 0.046 & 0.018 & 0.010 & 0.106 \\
\hline Metal manufacturing & 0.031 & 0.033 & 0.005 & 0.207 \\
\hline Textile manufacturing & 0.039 & 0.031 & 0.007 & 0.226 \\
\hline Share of all manufacturing workers in occupied labor force & 0.270 & 0.134 & 0.061 & 0.718 \\
\hline \multicolumn{5}{|l|}{ Basic demographic and geographic measures: } \\
\hline Share of population < 15 years 1849 & 0.351 & 0.028 & 0.228 & 0.414 \\
\hline Share of population > 60 years 1849 & 0.060 & 0.012 & 0.031 & 0.093 \\
\hline County area (in 1000 km²) & 0.812 & 0.450 & 0.002 & 2.541 \\
\hline \multicolumn{5}{|l|}{ Pre-industrial development: } \\
\hline Share of population living in cities 1816 & 0.248 & 0.187 & 0.000 & 1.000 \\
\hline Looms per capita 1819 & 0.008 & 0.019 & 0.000 & 0.233 \\
\hline Steam engines in mining (per 1000 inhabitants) 1849 & 0.015 & 0.086 & 0.000 & 1.010 \\
\hline Sheep per capita 1816 & 0.551 & 0.439 & 0.000 & 2.579 \\
\hline Share of farm laborers in total population 1819 & 0.095 & 0.040 & 0.000 & 0.241 \\
\hline Public buildings per capita 1821 & 0.004 & 0.003 & 0.000 & 0.021 \\
\hline Paved streets 1815 (dummy) & 0.222 & 0.416 & 0.000 & 1.000 \\
\hline Tonnage of transport ships (in 4000 p) per capita 1819 & 0.013 & 0.047 & 0.000 & 0.550 \\
\hline \multicolumn{5}{|l|}{ Additional demographic and geographic measures: } \\
\hline Distance to Wittenberg (in $1000 \mathrm{~km}$ ) & 0.333 & 0.165 & 0.000 & 0.731 \\
\hline Share Protestants 1816 & 0.598 & 0.399 & 0.000 & 1.000 \\
\hline Share Jews 1816 & 0.012 & 0.019 & 0.000 & 0.098 \\
\hline Year in which annexed by Prussia (divided by 1000) & 1.735 & 0.081 & 1.608 & 1.816 \\
\hline Western part & 0.281 & 0.450 & 0.000 & 1.000 \\
\hline Polish parts & 0.497 & 0.501 & 0.000 & 1.000 \\
\hline Distance to Berlin (in 1000 km) & 0.329 & 0.161 & 0.000 & 0.650 \\
\hline Distance to next province capital (in $1000 \mathrm{~km}$ ) & 0.085 & 0.043 & 0.000 & 0.280 \\
\hline Distance to London (in $1000 \mathrm{~km}$ ) & 0.940 & 0.328 & 0.416 & 1.534 \\
\hline Latitude (in rad) & 0.909 & 0.024 & 0.859 & 0.972 \\
\hline Longitude (in rad) & 0.239 & 0.084 & 0.105 & 0.394 \\
\hline
\end{tabular}

Source: Data for Prussian counties from different censuses; see Appendix A for details. 
TABLE 2: CORRELATIONS AMONG THE EDUCATION AND INDUSTRIALIZATION MEASURES

\begin{tabular}{|c|c|c|c|c|c|c|c|c|c|c|c|c|}
\hline & & $(1)$ & $(2)$ & (3) & (4) & (5) & (6) & (7) & $(8)$ & (9) & $(10)$ & $(11)$ \\
\hline & & A & $\mathrm{B}$ & $\mathrm{C}$ & $\mathrm{D}$ & $\mathrm{E}$ & $\mathrm{F}$ & G & $\mathrm{H}$ & I & $\mathrm{J}$ & $\mathrm{K}$ \\
\hline A & School enrollment rate 1816 & 1.000 & & & & & & & & & & \\
\hline $\mathrm{B}$ & School enrollment rate 1849 & $\begin{array}{c}0.543 \\
(0.000)\end{array}$ & 1.000 & & & & & & & & & \\
\hline \multirow[t]{2}{*}{$\mathrm{C}$} & Literacy rate 1871 & $\begin{array}{c}0.622 \\
(0.000)\end{array}$ & $\begin{array}{c}0.671 \\
(0.000)\end{array}$ & 1.000 & & & & & & & & \\
\hline & \multicolumn{12}{|l|}{ Share of factory workers in total population 1849 : } \\
\hline $\mathrm{D}$ & All factories & $\begin{array}{c}0.119 \\
(0.029)\end{array}$ & $\begin{array}{c}0.223 \\
(0.000)\end{array}$ & $\begin{array}{c}0.329 \\
(0.000)\end{array}$ & 1.000 & & & & & & & \\
\hline $\mathrm{E}$ & All factories except metals and textiles & $\begin{array}{c}0.214 \\
(0.000)\end{array}$ & $\begin{array}{c}0.248 \\
(0.000)\end{array}$ & $\begin{array}{c}0.343 \\
(0.000)\end{array}$ & $\begin{array}{c}0.599 \\
(0.000)\end{array}$ & 1.000 & & & & & & \\
\hline $\mathrm{F}$ & Metal factories & $\begin{array}{c}0.014 \\
(0.805)\end{array}$ & $\begin{array}{c}0.072 \\
(0.188)\end{array}$ & $\begin{array}{c}0.135 \\
(0.014)\end{array}$ & $\begin{array}{c}0.775 \\
(0.000)\end{array}$ & $\begin{array}{c}0.157 \\
(0.004)\end{array}$ & 1.000 & & & & & \\
\hline G & Textile factories & $\begin{array}{c}0.017 \\
(0.757)\end{array}$ & $\begin{array}{c}0.134 \\
(0.014)\end{array}$ & $\begin{array}{c}0.180 \\
(0.001)\end{array}$ & $\begin{array}{c}0.469 \\
(0.000)\end{array}$ & $\begin{array}{c}0.030 \\
(0.589)\end{array}$ & $\begin{array}{c}0.071 \\
(0.198)\end{array}$ & 1.000 & & & & \\
\hline \multicolumn{13}{|c|}{ Share of manufacturing workers in total population 1882: } \\
\hline $\mathrm{H}$ & All manufacturing & $\begin{array}{c}0.198 \\
(0.000)\end{array}$ & $\begin{array}{c}0.324 \\
(0.000)\end{array}$ & $\begin{array}{c}0.579 \\
(0.000)\end{array}$ & $\begin{array}{c}0.587 \\
(0.000)\end{array}$ & $\begin{array}{c}0.308 \\
(0.000)\end{array}$ & $\begin{array}{c}0.395 \\
(0.000)\end{array}$ & $\begin{array}{c}0.427 \\
(0.000)\end{array}$ & 1.000 & & & \\
\hline $\mathrm{I}$ & All manufacturing except metals and textiles & $\begin{array}{c}0.366 \\
(0.000)\end{array}$ & $\begin{array}{c}0.397 \\
(0.000)\end{array}$ & $\begin{array}{c}0.671 \\
(0.000)\end{array}$ & $\begin{array}{c}0.480 \\
(0.000)\end{array}$ & $\begin{array}{c}0.479 \\
(0.000)\end{array}$ & $\begin{array}{c}0.211 \\
(0.000)\end{array}$ & $\begin{array}{c}0.264 \\
(0.000)\end{array}$ & $\begin{array}{c}0.731 \\
(0.000)\end{array}$ & 1.000 & & \\
\hline $\mathrm{J}$ & Metal manufacturing & $\begin{array}{c}0.098 \\
(0.075)\end{array}$ & $\begin{array}{c}0.192 \\
(0.000)\end{array}$ & $\begin{array}{c}0.337 \\
(0.000)\end{array}$ & $\begin{array}{c}0.505 \\
(0.000)\end{array}$ & $\begin{array}{c}0.205 \\
(0.000)\end{array}$ & $\begin{array}{c}0.556 \\
(0.000)\end{array}$ & $\begin{array}{c}0.082 \\
(0.136)\end{array}$ & $\begin{array}{c}0.686 \\
(0.000)\end{array}$ & $\begin{array}{c}0.313 \\
(0.000)\end{array}$ & 1.000 & \\
\hline $\mathrm{K}$ & Textile manufacturing & $\begin{array}{c}0.055 \\
(0.320)\end{array}$ & $\begin{array}{c}0.169 \\
(0.002)\end{array}$ & $\begin{array}{c}0.330 \\
(0.000)\end{array}$ & $\begin{array}{c}0.279 \\
(0.000)\end{array}$ & $\begin{array}{c}0.080 \\
(0.143)\end{array}$ & $\begin{array}{c}0.025 \\
(0.648)\end{array}$ & $\begin{array}{c}0.548 \\
(0.000)\end{array}$ & $\begin{array}{c}0.705 \\
(0.000)\end{array}$ & $\begin{array}{c}0.447 \\
(0.000)\end{array}$ & $\begin{array}{c}0.039 \\
(0.483)\end{array}$ & 1.000 \\
\hline
\end{tabular}

Notes: Number of observations: 334. $p$ values in parentheses.

Source: Data for Prussian counties from different censuses; see Appendix A for details. 
TABLE 3: EDUCATION AND INDUSTRIALIZATION IN THE FIRST PHASE OF THE INDUSTRIAL REVOLUTION

\begin{tabular}{|c|c|c|c|c|c|c|c|c|c|c|}
\hline \multirow{4}{*}{ Dependent variable: } & \multicolumn{4}{|c|}{ OLS } & \multirow{3}{*}{$\begin{array}{l}\text { Reduced } \\
\text { form }\end{array}$} & \multicolumn{5}{|c|}{ IV } \\
\hline & & & & & & $1^{\text {st }}$ stage & & $2^{\text {nd }} s$ & & \\
\hline & \multicolumn{4}{|c|}{ Share of factory workers in total population 1849} & & \multirow{2}{*}{$\begin{array}{c}\text { School } \\
\text { enrollment } \\
\text { rate } 1849 \\
\text { (6) }\end{array}$} & \multicolumn{4}{|c|}{ Share of factory workers in total population 1849} \\
\hline & $\begin{array}{c}\text { All } \\
\text { factories } \\
\text { (1) }\end{array}$ & $\begin{array}{c}\text { All except } \\
\text { metal+text. } \\
\text { (2) }\end{array}$ & $\begin{array}{c}\text { Metal } \\
\text { factories } \\
\text { (3) }\end{array}$ & $\begin{array}{c}\text { Textile } \\
\text { factories } \\
\text { (4) }\end{array}$ & $\begin{array}{c}\text { All } \\
\text { factories } \\
(5)\end{array}$ & & $\begin{array}{c}\text { All } \\
\text { factories } \\
\text { (7) }\end{array}$ & $\begin{array}{l}\text { All except } \\
\text { metal+text. } \\
\text { (8) }\end{array}$ & $\begin{array}{c}\text { Metal } \\
\text { factories } \\
\text { (9) }\end{array}$ & $\begin{array}{c}\text { Textile } \\
\text { factories } \\
(10)\end{array}$ \\
\hline School enrollment rate 1849 & $\begin{array}{c}0.031^{* * *} \\
(0.007)\end{array}$ & $\begin{array}{c}0.020^{* * *} \\
(0.005)\end{array}$ & $\begin{array}{l}0.009^{* *} \\
(0.004)\end{array}$ & $\begin{array}{c}0.002 \\
(0.003)\end{array}$ & & & $\begin{array}{l}0.031^{*} \\
(0.018)\end{array}$ & $\begin{array}{c}0.032^{* * *} \\
(0.010)\end{array}$ & $\begin{array}{c}0.010 \\
(0.011)\end{array}$ & $\begin{array}{c}-0.011 \\
(0.008)\end{array}$ \\
\hline School enrollment rate 1816 & & & & & $\begin{array}{c}0.008^{*} \\
(0.005)\end{array}$ & $\begin{array}{c}0.258^{* * *} \\
(0.031)\end{array}$ & & & & \\
\hline Share of population $<15$ years & $\begin{array}{l}-0.045 \\
(0.043)\end{array}$ & $\begin{array}{c}-0.064^{* *} \\
(0.025)\end{array}$ & $\begin{array}{c}0.031 \\
(0.024)\end{array}$ & $\begin{array}{l}-0.012 \\
(0.015)\end{array}$ & $\begin{array}{l}-0.017 \\
(0.046)\end{array}$ & $\begin{array}{c}0.925^{* * *} \\
(0.269)\end{array}$ & $\begin{array}{l}-0.045 \\
(0.042)\end{array}$ & $\begin{array}{c}-0.071^{* * *} \\
(0.025)\end{array}$ & $\begin{array}{c}0.031 \\
(0.022)\end{array}$ & $\begin{array}{l}-0.004 \\
(0.016)\end{array}$ \\
\hline Share of population $>60$ years & $\begin{array}{c}-0.189^{*} \\
(0.099)\end{array}$ & $\begin{array}{c}-0.179^{* * *} \\
(0.068)\end{array}$ & $\begin{array}{c}-0.083 \\
(0.051)\end{array}$ & $\begin{array}{l}0.074^{*} \\
(0.041)\end{array}$ & $\begin{array}{c}-0.064 \\
(0.093)\end{array}$ & $\begin{array}{c}4.040^{* * *} \\
(0.577)\end{array}$ & $\begin{array}{l}-0.189 \\
(0.134)\end{array}$ & $\begin{array}{c}-0.244^{* * *} \\
(0.086)\end{array}$ & $\begin{array}{l}-0.091 \\
(0.072)\end{array}$ & $\begin{array}{l}0.146^{* *} \\
(0.061)\end{array}$ \\
\hline County area (in $1000 \mathrm{~km}^{2}$ ) & $\begin{array}{c}-0.010^{* * *} \\
(0.002)\end{array}$ & $\begin{array}{c}-0.004^{* * *} \\
(0.001)\end{array}$ & $\begin{array}{c}-0.004^{* *} \\
(0.002)\end{array}$ & $\begin{array}{c}-0.002^{* *} \\
(0.001)\end{array}$ & $\begin{array}{c}-0.011^{* * *} \\
(0.002)\end{array}$ & $\begin{array}{c}-0.036^{* * *} \\
(0.011)\end{array}$ & $\begin{array}{c}-0.010^{* * *} \\
(0.002)\end{array}$ & $\begin{array}{c}-0.003^{* * *} \\
(0.001)\end{array}$ & $\begin{array}{c}-0.004^{* *} \\
(0.002)\end{array}$ & $\begin{array}{c}-0.002^{* *} \\
(0.001)\end{array}$ \\
\hline Constant & $\begin{array}{c}0.028 \\
(0.018)\end{array}$ & $\begin{array}{l}0.030^{* *} \\
(0.012)\end{array}$ & $\begin{array}{l}-0.004 \\
(0.009)\end{array}$ & $\begin{array}{c}0.002 \\
(0.006)\end{array}$ & $\begin{array}{c}0.032 \\
(0.019)\end{array}$ & $\begin{array}{c}0.114 \\
(0.123)\end{array}$ & $\begin{array}{c}0.028 \\
(0.020)\end{array}$ & $\begin{array}{l}0.026^{* *} \\
(0.012)\end{array}$ & $\begin{array}{l}-0.005 \\
(0.011)\end{array}$ & $\begin{array}{c}0.007 \\
(0.006)\end{array}$ \\
\hline $\begin{array}{l}\text { Observations } \\
R^{2} \\
1^{\text {st }} \text {-stage } F \text { statistic }\end{array}$ & $\begin{array}{c}334 \\
0.123\end{array}$ & $\begin{array}{c}334 \\
0.152\end{array}$ & $\begin{array}{c}334 \\
0.038\end{array}$ & $\begin{array}{c}334 \\
0.060\end{array}$ & $\begin{array}{c}334 \\
0.097\end{array}$ & $\begin{array}{c}334 \\
0.423 \\
69.69\end{array}$ & $\begin{array}{c}334 \\
0.123\end{array}$ & $\begin{array}{c}334 \\
0.130\end{array}$ & $\begin{array}{c}334 \\
0.037\end{array}$ & $\begin{array}{c}334 \\
0.022\end{array}$ \\
\hline
\end{tabular}

Notes: Standard errors (adjusted for clustering by 280 original counties) in parentheses: significance at ${ }^{* * *} 1,^{* *} 5,^{*} 10$ percent.

Source: Data for Prussian counties from different censuses; see Appendix A for details. 
TABle 4: ACCOUnting FOR PRE-INDUSTRIAL DeVELOPMENT

\begin{tabular}{|c|c|c|c|c|c|c|c|c|c|c|}
\hline \multirow[t]{2}{*}{ "Dependent variable: } & \multicolumn{5}{|c|}{ Share of factory workers in total population 1849} & \multirow{2}{*}{$\begin{array}{c}\text { School } \\
\text { enrollment } \\
\text { rate } 1849 \\
(6)^{\mathrm{b}} \\
\end{array}$} & \multicolumn{4}{|c|}{ Share of factory workers in total popul. 1849} \\
\hline & $(1)$ & $(2)$ & $\begin{array}{l}\text { All factorie } \\
\text { (3) }\end{array}$ & $(4)$ & $(5)^{\mathrm{a}}$ & & $\begin{array}{c}\text { All } \\
\text { factories } \\
(7) \\
\end{array}$ & $\begin{array}{l}\text { All except } \\
\text { metal+text. } \\
(8)\end{array}$ & $\begin{array}{c}\text { Metal } \\
\text { factories } \\
(9) \\
\end{array}$ & $\begin{array}{c}\text { Textile } \\
\text { factories } \\
(10)\end{array}$ \\
\hline School enrollment rate 1849 & $\begin{array}{l}0.036^{* *} \\
(0.017)\end{array}$ & $\begin{array}{l}0.034^{* *} \\
(0.017)\end{array}$ & $\begin{array}{l}0.040^{* * *} \\
(0.015)\end{array}$ & $\begin{array}{l}0.037^{* *} \\
(0.016)\end{array}$ & & & $\begin{array}{l}0.052^{* *} \\
(0.023)\end{array}$ & $\begin{array}{l}0.035^{* * *} \\
(0.014)\end{array}$ & $\begin{array}{l}0.030^{*} \\
(0.017)\end{array}$ & $\begin{array}{l}-0.014 \\
(0.009)\end{array}$ \\
\hline School enrollment rate 1816 & & & & & $\begin{array}{l}0.011^{* *} \\
(0.005)\end{array}$ & $\begin{array}{c}0.209^{* * *} \\
(0.033)\end{array}$ & & & & \\
\hline Share of population $<15$ years & $\begin{array}{c}0.035 \\
(0.045)\end{array}$ & $\begin{array}{c}0.028 \\
(0.043)\end{array}$ & $\begin{array}{c}0.010 \\
(0.042)\end{array}$ & $\begin{array}{c}0.023 \\
(0.046)\end{array}$ & $\begin{array}{c}0.054 \\
(0.052)\end{array}$ & $\begin{array}{l}0.845^{* * *} \\
(0.308)\end{array}$ & $\begin{array}{c}0.010 \\
(0.046)\end{array}$ & $\begin{array}{l}-0.038 \\
(0.024)\end{array}$ & $\begin{array}{c}0.032 \\
(0.029)\end{array}$ & $\begin{array}{c}0.016 \\
(0.020)\end{array}$ \\
\hline Share of population $>60$ years & $\begin{array}{l}-0.061 \\
(0.128)\end{array}$ & $\begin{array}{l}-0.080 \\
(0.123)\end{array}$ & $\begin{array}{l}-0.102 \\
(0.113)\end{array}$ & $\begin{array}{l}-0.064 \\
(0.116)\end{array}$ & $\begin{array}{c}0.100 \\
(0.075)\end{array}$ & $\begin{array}{c}3.987^{* * *} \\
(0.604)\end{array}$ & $\begin{array}{l}-0.107 \\
(0.128)\end{array}$ & $\begin{array}{l}-0.187^{* *} \\
(0.089)\end{array}$ & $\begin{array}{l}-0.117 \\
(0.073)\end{array}$ & $\begin{array}{c}0.197^{* * *} \\
(0.065)\end{array}$ \\
\hline County area (in 1000 km²) & $\begin{array}{l}-0.009^{* * *} \\
(0.002)\end{array}$ & $\begin{array}{l}-0.008^{* * *} \\
(0.002)\end{array}$ & $\begin{array}{l}-0.006^{* * *} \\
(0.002)\end{array}$ & $\begin{array}{l}-0.005^{* * *} \\
(0.002)\end{array}$ & $\begin{array}{l}-0.005^{* *} \\
(0.002)\end{array}$ & $\begin{array}{l}-0.032^{* * *} \\
(0.012)\end{array}$ & $\begin{array}{l}-0.004^{* *} \\
(0.002)\end{array}$ & $\begin{array}{l}-0.003^{* * *} \\
(0.001)\end{array}$ & $\begin{array}{r}-0.0002 \\
(0.001)\end{array}$ & $\begin{array}{l}-0.001 \\
(0.001)\end{array}$ \\
\hline $\begin{array}{l}\text { Share of population living in } \\
\text { cities } 1816\end{array}$ & $\begin{array}{l}0.020^{* * *} \\
(0.006)\end{array}$ & $\begin{array}{l}0.016^{* * *} \\
(0.006)\end{array}$ & $\begin{array}{l}0.017^{* * *} \\
(0.006)\end{array}$ & $\begin{array}{l}0.017^{* * *} \\
(0.006)\end{array}$ & $\begin{array}{l}0.020^{* * *} \\
(0.007)\end{array}$ & $\begin{array}{l}-0.024 \\
(0.044)\end{array}$ & $\begin{array}{l}0.021^{* * *} \\
(0.008)\end{array}$ & $\begin{array}{l}0.009^{* * *} \\
(0.003)\end{array}$ & $\begin{array}{c}0.007 \\
(0.005)\end{array}$ & $\begin{array}{l}0.005 \\
(0.003)\end{array}$ \\
\hline Looms per capita 1819 & & $\begin{array}{l}0.188^{* * *} \\
(0.048)\end{array}$ & $\begin{array}{l}0.174^{* * *} \\
(0.047)\end{array}$ & $\begin{array}{l}0.167^{* * * *} \\
(0.046)\end{array}$ & $\begin{array}{l}0.155^{* * *} \\
(0.047)\end{array}$ & $\begin{array}{l}0.264^{* *} \\
(0.133)\end{array}$ & $\begin{array}{l}0.141^{* * *} \\
(0.047)\end{array}$ & $\begin{array}{c}0.013 \\
(0.020)\end{array}$ & $\begin{array}{c}0.049 \\
(0.036)\end{array}$ & $\begin{array}{l}0.079^{* *} \\
(0.040)\end{array}$ \\
\hline $\begin{array}{l}\text { Steam engines in mining per } \\
\text { capita } 1849\end{array}$ & & & $\begin{array}{c}0.043^{* * *} \\
(0.007)\end{array}$ & $\begin{array}{c}0.043^{* * *} \\
(0.007)\end{array}$ & $\begin{array}{l}0.044^{* * *} \\
(0.005)\end{array}$ & $\begin{array}{c}0.062 \\
(0.050)\end{array}$ & $\begin{array}{c}0.040^{* * * *} \\
(0.006)\end{array}$ & $\begin{array}{l}-0.001 \\
(0.004)\end{array}$ & $\begin{array}{l}0.036^{* * *} \\
(0.004)\end{array}$ & $\begin{array}{c}0.005 \\
(0.004)\end{array}$ \\
\hline Sheep per capita 1816 & & & & $\begin{array}{l}-0.001 \\
(0.002)\end{array}$ & $\begin{array}{r}-0.0004 \\
(0.002)\end{array}$ & $\begin{array}{c}0.015 \\
(0.014)\end{array}$ & $\begin{array}{l}-0.001 \\
(0.002)\end{array}$ & $\begin{array}{l}0.002^{*} \\
(0.001)\end{array}$ & $\begin{array}{l}-0.002^{*} \\
(0.001)\end{array}$ & $\begin{array}{r}-0.0004 \\
(0.001)\end{array}$ \\
\hline $\begin{array}{c}\text { Share of farm laborers in } \\
\text { total population } 1819\end{array}$ & & & & $\begin{array}{l}-0.043^{* *} \\
(0.017)\end{array}$ & $\begin{array}{c}-0.059^{* * *} \\
(0.017)\end{array}$ & $\begin{array}{l}-0.337^{* *} \\
(0.144)\end{array}$ & $\begin{array}{l}-0.041^{* *} \\
(0.018)\end{array}$ & $\begin{array}{l}0.005 \\
(0.010)\end{array}$ & $\begin{array}{l}-0.009 \\
(0.010)\end{array}$ & $\begin{array}{c}-0.038^{* * *} \\
(0.012)\end{array}$ \\
\hline Public buildings per capita 1821 & & & & & $\begin{array}{l}-0.267 \\
(0.284)\end{array}$ & $\begin{array}{l}5.462^{* * *} \\
(1.471)\end{array}$ & $\begin{array}{l}-0.550 \\
(0.359)\end{array}$ & $\begin{array}{l}-0.109 \\
(0.207)\end{array}$ & $\begin{array}{l}-0.488^{* *} \\
(0.236)\end{array}$ & $\begin{array}{c}0.046 \\
(0.148)\end{array}$ \\
\hline Paved streets 1815 (dummy) & & & & & $\begin{array}{c}0.003 \\
(0.002)\end{array}$ & $\begin{array}{c}0.018 \\
(0.011)\end{array}$ & $\begin{array}{c}0.002 \\
(0.003)\end{array}$ & $\begin{array}{l}0.003^{*} \\
(0.001)\end{array}$ & $\begin{array}{l}0.0002 \\
(0.002)\end{array}$ & $\begin{array}{l}-0.001 \\
(0.001)\end{array}$ \\
\hline $\begin{array}{l}\text { Tonnage of ships per } \\
\text { capita } 1819\end{array}$ & & & & & $\begin{array}{l}-0.031^{*} \\
(0.017)\end{array}$ & $\begin{array}{l}-0.005 \\
(0.249)\end{array}$ & $\begin{array}{l}-0.031^{* *} \\
(0.013)\end{array}$ & $\begin{array}{l}-0.003 \\
(0.006)\end{array}$ & $\begin{array}{l}-0.013 \\
(0.010)\end{array}$ & $\begin{array}{c}-0.014^{* *} \\
(0.007)\end{array}$ \\
\hline Constant & $\begin{array}{l}-0.017 \\
(0.020) \\
\end{array}$ & $\begin{array}{c}-0.014 \\
(0.019) \\
\end{array}$ & $\begin{array}{l}-0.013 \\
(0.019) \\
\end{array}$ & $\begin{array}{l}-0.013 \\
(0.021)\end{array}$ & $\begin{array}{l}-0.009 \\
(0.020) \\
\end{array}$ & $\begin{array}{c}0.169 \\
(0.149) \\
\end{array}$ & $\begin{array}{l}-0.018 \\
(0.023) \\
\end{array}$ & $\begin{array}{c}0.004 \\
(0.011) \\
\end{array}$ & $\begin{array}{l}-0.021 \\
(0.017)\end{array}$ & $\begin{array}{l}-0.001 \\
(0.009)\end{array}$ \\
\hline $\begin{array}{l}\text { Observations } \\
R^{2} \\
1^{\text {st }} \text {-stage } F \text { statistic }\end{array}$ & $\begin{array}{c}334 \\
0.155\end{array}$ & $\begin{array}{c}334 \\
0.199\end{array}$ & $\begin{array}{c}334 \\
0.244\end{array}$ & $\begin{array}{c}334 \\
0.256\end{array}$ & $\begin{array}{c}334 \\
0.262\end{array}$ & $\begin{array}{c}334 \\
0.465 \\
41.29 \\
\end{array}$ & $\begin{array}{c}334 \\
0.253\end{array}$ & $\begin{array}{c}334 \\
0.176\end{array}$ & $\begin{array}{c}334 \\
0.130\end{array}$ & $\begin{array}{c}334 \\
0.132\end{array}$ \\
\hline
\end{tabular}

Notes: Instrumental-variable estimates, with school enrollment rate 1849 instrumented by school enrollment rate 1816. Standard errors (adjusted for clustering by 280 original counties) in parentheses: significance at ${ }^{* * *} 1,{ }^{* *} 5,{ }^{*} 10$ percent. ${ }^{\text {a }}$ Reduced form (OLS, not instrumented). ${ }^{\mathrm{b}}$ First stage for columns (7) to (10).

Source: Data for Prussian counties from different censuses; see Appendix A for details. 


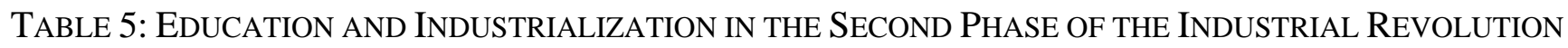

\begin{tabular}{|c|c|c|c|c|c|c|c|c|c|c|}
\hline \multirow{3}{*}{ Dependent variable: } & \multicolumn{4}{|c|}{ OLS } & \multirow{3}{*}{$\begin{array}{c}\begin{array}{c}\text { Reduced } \\
\text { form }\end{array} \\
\begin{array}{c}\text { All manu- } \\
\text { facturing } \\
\text { (5) }\end{array}\end{array}$} & \multicolumn{5}{|c|}{ IV } \\
\hline & \multicolumn{4}{|c|}{ Share of manuf. workers in total popul. 1882} & & \multirow[b]{2}{*}{$\begin{array}{c}\text { Literacy } \\
\text { rate } 1871 \\
(6)\end{array}$} & \multicolumn{4}{|c|}{$\begin{array}{c}2^{\text {nd }} \text { stage } \\
\text { Share of manuf. workers in total popul. } 1882\end{array}$} \\
\hline & $\begin{array}{c}\text { All manu- } \\
\text { facturing } \\
(1)\end{array}$ & $\begin{array}{c}\text { All except } \\
\text { metal+text. } \\
(2)\end{array}$ & $\begin{array}{c}\text { Metal } \\
\text { manufact. } \\
(3)\end{array}$ & $\begin{array}{c}\text { Textile } \\
\text { manufact. } \\
(4)\end{array}$ & & & $\begin{array}{c}\text { All manu- } \\
\text { facturing } \\
(7)\end{array}$ & $\begin{array}{c}\text { All except } \\
\text { metal+text. } \\
(8)\end{array}$ & $\begin{array}{c}\text { Metal } \\
\text { manufact. } \\
(9)\end{array}$ & $\begin{array}{c}\text { Textile } \\
\text { manufact. } \\
(10)\end{array}$ \\
\hline \multirow[t]{2}{*}{ Literacy rate 1871} & $0.179^{* * *}$ & $0.062^{* * *}$ & $0.103^{* * *}$ & 0.013 & & & $0.100^{* *}$ & $0.067^{* * *}$ & $0.091^{* * *}$ & $-0.057^{*}$ \\
\hline & $(0.023)$ & $(0.008)$ & $(0.018)$ & $(0.012)$ & & & $(0.043)$ & $(0.014)$ & $(0.032)$ & $(0.031)$ \\
\hline School enrollment rate 1816 & & & & & $\begin{array}{l}0.028^{* *} \\
(0.013)\end{array}$ & $\begin{array}{c}0.280^{* * *} \\
(0.035)\end{array}$ & & & & \\
\hline \multirow[t]{2}{*}{ Share of population $<15$ years } & -0.055 & $-0.071^{* *}$ & $0.159^{*}$ & -0.143 & -0.050 & 0.258 & -0.076 & $-0.070^{* *}$ & $0.156^{* *}$ & $-0.161^{*}$ \\
\hline & $(0.119)$ & $(0.035)$ & $(0.082)$ & $(0.088)$ & $(0.137)$ & $(0.298)$ & $(0.120)$ & $(0.034)$ & $(0.079)$ & $(0.092)$ \\
\hline \multirow[t]{2}{*}{ Share of population $>60$ years } & 0.134 & -0.029 & $-0.353^{*}$ & $0.516^{* *}$ & $1.012^{* * *}$ & $4.648^{* * *}$ & 0.547 & -0.052 & -0.288 & $0.887^{* * *}$ \\
\hline & $(0.266)$ & $(0.081)$ & $(0.186)$ & $(0.210)$ & $(0.255)$ & $(0.617)$ & $(0.339)$ & $(0.105)$ & $(0.234)$ & $(0.256)$ \\
\hline \multirow[t]{2}{*}{ County area (in 1000 km²) } & $-0.010^{* *}$ & $-0.004^{*}$ & -0.0005 & $-0.006^{*}$ & $-0.024^{* * *}$ & $-0.074^{* * *}$ & $-0.016^{* *}$ & -0.003 & -0.001 & $-0.012^{* *}$ \\
\hline & $(0.005)$ & $(0.002)$ & $(0.002)$ & $(0.003)$ & $(0.006)$ & $(0.015)$ & $(0.006)$ & $(0.002)$ & $(0.004)$ & $(0.005)$ \\
\hline \multirow{2}{*}{$\begin{array}{l}\text { Share of population living in } \\
\text { cities } 1816\end{array}$} & $0.044^{* * *}$ & $0.025^{* * *}$ & 0.001 & 0.017 & $0.053^{* * *}$ & $0.078^{* *}$ & $0.045^{* * *}$ & $0.025^{* * *}$ & 0.002 & 0.019 \\
\hline & $(0.015)$ & $(0.004)$ & $(0.008)$ & $(0.012)$ & $(0.017)$ & $(0.038)$ & $(0.015)$ & $(0.004)$ & $(0.008)$ & $(0.012)$ \\
\hline \multirow[t]{2}{*}{ Looms per capita 1819} & $0.854^{* * *}$ & 0.052 & 0.115 & $0.687^{* *}$ & $0.945^{* * *}$ & $0.424^{* *}$ & $0.903^{* * *}$ & 0.049 & $0.122^{*}$ & $0.731^{* *}$ \\
\hline & $(0.297)$ & $(0.040)$ & $(0.071)$ & $(0.302)$ & $(0.310)$ & $(0.171)$ & $(0.296)$ & $(0.040)$ & $(0.070)$ & $(0.302)$ \\
\hline \multirow{2}{*}{$\begin{array}{l}\text { Steam engines in mining per } \\
\text { capita } 1849\end{array}$} & $0.176^{* * *}$ & 0.001 & $0.194^{* * *}$ & -0.019 & $0.177^{* * *}$ & 0.022 & $0.175^{* * *}$ & 0.001 & $0.193^{* * *}$ & -0.020 \\
\hline & $(0.016)$ & $(0.005)$ & $(0.026)$ & $(0.014)$ & (0.019) & $(0.032)$ & $(0.018)$ & $(0.005)$ & $(0.026)$ & $(0.012)$ \\
\hline \multirow[t]{2}{*}{ Sheep per capita 1816} & $-0.021^{* * *}$ & $-0.004^{* *}$ & $-0.010^{* * *}$ & $-0.007^{* *}$ & $-0.013^{* *}$ & $0.042^{* * *}$ & $-0.017^{* * *}$ & $-0.004^{* *}$ & $-0.010^{* * *}$ & -0.003 \\
\hline & $(0.005)$ & $(0.002)$ & $(0.003)$ & (0.003) & $(0.005)$ & $(0.012)$ & $(0.005)$ & $(0.002)$ & $(0.003)$ & $(0.003)$ \\
\hline \multirow{2}{*}{$\begin{array}{c}\text { Share of farm laborers in } \\
\text { total population } 1819\end{array}$} & $-0.095^{*}$ & -0.002 & -0.047 & -0.046 & $-0.164^{* * *}$ & $-0.369^{* * *}$ & $-0.127^{* *}$ & 0.0002 & -0.052 & $-0.075^{* *}$ \\
\hline & $(0.052)$ & $(0.016)$ & $(0.031)$ & $(0.042)$ & $(0.057)$ & $(0.117)$ & $(0.053)$ & $(0.017)$ & $(0.038)$ & $(0.038)$ \\
\hline \multirow[t]{2}{*}{ Public buildings per capita 1821} & $-1.903^{* * *}$ & 0.025 & $-0.657^{*}$ & $-1.271^{* * *}$ & -0.946 & 2.122 & $-1.158^{*}$ & -0.017 & -0.541 & -0.600 \\
\hline & $(0.558)$ & $(0.212)$ & $(0.359)$ & $(0.373)$ & (0.694) & (1.607) & $(0.662)$ & $(0.220)$ & $(0.465)$ & $(0.397)$ \\
\hline \multirow[t]{2}{*}{ Paved streets 1815 (dummy) } & 0.007 & $0.006^{* * *}$ & 0.005 & -0.004 & $0.018^{* * *}$ & $0.057^{* * *}$ & $0.013^{* *}$ & $0.006^{* * *}$ & 0.006 & 0.001 \\
\hline & $(0.006)$ & $(0.002)$ & $(0.004)$ & $(0.004)$ & (0.006) & (0.010) & (0.006) & $(0.002)$ & $(0.004)$ & $(0.004)$ \\
\hline \multirow{2}{*}{$\begin{array}{l}\text { Tonnage of ships per } \\
\text { capita } 1819\end{array}$} & -0.020 & 0.022 & -0.008 & -0.035 & -0.016 & 0.005 & -0.017 & $0.022^{*}$ & -0.007 & -0.032 \\
\hline & $(0.033)$ & $(0.014)$ & $(0.023)$ & $(0.021)$ & $(0.036)$ & $(0.136)$ & $(0.033)$ & $(0.013)$ & $(0.022)$ & $(0.021)$ \\
\hline \multirow[t]{2}{*}{ Constant } & -0.008 & 0.018 & $-0.082^{* *}$ & 0.057 & 0.074 & $0.332^{* *}$ & 0.041 & 0.015 & $-0.074^{* *}$ & $0.101^{* *}$ \\
\hline & $(0.054)$ & $(0.017)$ & $(0.036)$ & $(0.039)$ & $(0.060)$ & $(0.139)$ & $(0.058)$ & $(0.017)$ & $(0.037)$ & $(0.047)$ \\
\hline Observations & 334 & 334 & 334 & 334 & 334 & 334 & 334 & 334 & 334 & 334 \\
\hline$R^{2}$ & 0.672 & 0.663 & 0.503 & 0.451 & 0.602 & 0.683 & 0.658 & 0.662 & 0.502 & 0.410 \\
\hline $1^{\text {st }}$-stage $F$ statistic & & & & & & 63.34 & & & & \\
\hline
\end{tabular}

Notes: Standard errors (adjusted for clustering by 280 original counties) in parentheses: significance at ${ }^{* * *} 1,^{* *} 5,^{*} 10$ percent.

Source: Data for Prussian counties from different censuses; see Appendix A for details. 
TABle 6: The Progress of INDUSTRIALIZATION BETWEEN 1849 AND 1882

\begin{tabular}{|c|c|c|c|c|c|}
\hline & \multirow{2}{*}{$\begin{array}{c}\text { Literacy } \\
\text { rate } \\
1871 \\
(1)\end{array}$} & \multicolumn{4}{|c|}{ Share of manufacturing workers in total population 1882} \\
\hline Dependent variable: & & $\begin{array}{c}\text { All } \\
\text { manufacturing } \\
(2) \\
\end{array}$ & $\begin{array}{c}\text { All except } \\
\text { metals and textiles } \\
\text { (3) }\end{array}$ & $\begin{array}{c}\text { Metal } \\
\text { manufacturing } \\
(4) \\
\end{array}$ & $\begin{array}{c}\text { Textile } \\
\text { manufacturing } \\
(5) \\
\end{array}$ \\
\hline Literacy rate 1871 & & $\begin{array}{l}0.088^{* *} \\
(0.034)\end{array}$ & $\begin{array}{c}0.062^{* * *} \\
(0.012)\end{array}$ & $\begin{array}{c}0.064^{* * *} \\
(0.024)\end{array}$ & $\begin{array}{l}-0.018 \\
(0.018)\end{array}$ \\
\hline $\begin{array}{l}\text { School enrollment rate } 1816 \\
\text { School enrollment rate } 1849\end{array}$ & $\begin{array}{l}0.205^{* * *} \\
(0.035) \\
0.326^{* * *} \\
(0.054)\end{array}$ & & & & \\
\hline Share of factory workers in total population $1849^{\mathrm{a}}$ & $\begin{array}{l}0.705^{* * *} \\
(0.221)\end{array}$ & $\begin{array}{l}0.921^{* * *} \\
(0.149)\end{array}$ & $\begin{array}{l}0.362^{* * *} \\
(0.129)\end{array}$ & $\begin{array}{l}0.981^{* * *} \\
(0.226)\end{array}$ & $\begin{array}{l}1.691^{* * *} \\
(0.455)\end{array}$ \\
\hline Share of population living in cities 1816 & $\begin{array}{l}0.072^{* *} \\
(0.032)\end{array}$ & $\begin{array}{l}0.029^{* *} \\
(0.013)\end{array}$ & $\begin{array}{c}0.023^{* * *} \\
(0.004)\end{array}$ & $\begin{array}{l}-0.002 \\
(0.007)\end{array}$ & $\begin{array}{c}0.008 \\
(0.010)\end{array}$ \\
\hline Looms per capita 1819 & $\begin{array}{c}0.228 \\
(0.148)\end{array}$ & $\begin{array}{l}0.760^{* * *} \\
(0.285)\end{array}$ & $\begin{array}{c}0.042 \\
(0.039)\end{array}$ & $\begin{array}{l}0.078^{*} \\
(0.047)\end{array}$ & $\begin{array}{l}0.583^{* *} \\
(0.256)\end{array}$ \\
\hline Steam engines in mining per capita 1849 & $\begin{array}{l}-0.030 \\
(0.033)\end{array}$ & $\begin{array}{l}0.136^{* * *} \\
(0.020)\end{array}$ & $\begin{array}{c}0.001 \\
(0.005)\end{array}$ & $\begin{array}{l}0.157^{* * *} \\
(0.028)\end{array}$ & $\begin{array}{l}-0.027^{* *} \\
(0.013)\end{array}$ \\
\hline Sheep per capita 1816 & $\begin{array}{l}0.037^{* * *} \\
(0.011)\end{array}$ & $\begin{array}{c}-0.017^{* * *} \\
(0.004)\end{array}$ & $\begin{array}{l}-0.005^{* * *} \\
(0.002)\end{array}$ & $\begin{array}{c}-0.007^{* *} \\
(0.003)\end{array}$ & $\begin{array}{l}-0.004^{*} \\
(0.002)\end{array}$ \\
\hline Share of farm laborers in total pop. 1819 & $\begin{array}{l}-0.218^{*} \\
(0.114)\end{array}$ & $\begin{array}{l}-0.077 \\
(0.049)\end{array}$ & $\begin{array}{c}0.001 \\
(0.016)\end{array}$ & $\begin{array}{l}-0.044 \\
(0.032)\end{array}$ & $\begin{array}{l}-0.004 \\
(0.033)\end{array}$ \\
\hline Public buildings per capita 1821 & $\begin{array}{c}0.531 \\
(1.356)\end{array}$ & $\begin{array}{l}-1.064^{*} \\
(0.554)\end{array}$ & $\begin{array}{l}-0.074 \\
(0.201)\end{array}$ & $\begin{array}{l}-0.137 \\
(0.390)\end{array}$ & $\begin{array}{l}-0.794^{* *} \\
(0.327)\end{array}$ \\
\hline Paved streets 1815 (dummy) & $\begin{array}{c}0.049^{* * *} \\
(0.009)\end{array}$ & $\begin{array}{l}0.010^{*} \\
(0.005)\end{array}$ & $\begin{array}{l}0.005^{* *} \\
(0.002)\end{array}$ & $\begin{array}{l}0.007^{*} \\
(0.004)\end{array}$ & $\begin{array}{l}0.0001 \\
(0.003)\end{array}$ \\
\hline Tonnage of ships per capita 1819 & $\begin{array}{c}0.029 \\
(0.097)\end{array}$ & $\begin{array}{c}0.011 \\
(0.030)\end{array}$ & $\begin{array}{l}0.023^{* *} \\
(0.012)\end{array}$ & $\begin{array}{c}0.007 \\
(0.019)\end{array}$ & $\begin{array}{l}-0.009 \\
(0.015)\end{array}$ \\
\hline Observations & 334 & 334 & 334 & 334 & 334 \\
\hline $\begin{array}{l}R^{2} \\
1^{\text {st }} \text {-stage } F \text { statistic }\end{array}$ & $\begin{array}{l}0.735 \\
55.24\end{array}$ & 0.707 & 0.685 & 0.589 & 0.556 \\
\hline $\begin{array}{l}\text { Hansen-Sargan } J \text { statistic } \\
\quad p \text { value }\end{array}$ & & $\begin{array}{l}1.245 \\
0.265 \\
\end{array}$ & $\begin{array}{l}0.549 \\
0.459 \\
\end{array}$ & $\begin{array}{l}0.081 \\
0.776 \\
\end{array}$ & $\begin{array}{l}2.290 \\
0.130 \\
\end{array}$ \\
\hline
\end{tabular}

Notes: Instrumental-variable estimates, with literacy rate 1871 instrumented by school enrollment rate 1816 and school enrollment rate 1849 . Additional controls: share of population < 15 years, share of population $>60$ years, county area (in $1000 \mathrm{~km}^{2}$ ), and a constant. Column (1) reports the first stage for column (2). Standard errors (adjusted for clustering by 280 original counties) in parentheses: significance at ${ }^{* * *} 1,{ }^{* *} 5,{ }^{*} 10$ percent.

${ }^{a}$ Columns (1) and (2): all factories; column (3): all factories except metals and textiles; column (4): metal factories; column (5): textile factories.

Source: Data for Prussian counties from different censuses; see Appendix A for details. 
TABLE 7: DistanCE to WitTENBERG AS AN ALteRnATIVE INSTRUMENT

\begin{tabular}{|c|c|c|c|c|c|c|c|c|}
\hline \multirow[t]{2}{*}{ Dependent variable: } & \multirow{2}{*}{$\begin{array}{c}\text { School } \\
\text { enrollment } \\
\text { rate } 1849 \\
(1)\end{array}$} & \multicolumn{3}{|c|}{ "Share of factory workers in pop. 1849} & \multirow{2}{*}{$\begin{array}{l}\text { Literacy } \\
\text { rate } \\
1871 \\
(5)\end{array}$} & \multicolumn{3}{|c|}{ "Share of manuf. workers in pop. 1882} \\
\hline & & $\begin{array}{c}\text { All } \\
\text { factories } \\
(2)\end{array}$ & $\begin{array}{l}\text { All except } \\
\text { metal+text. } \\
\text { (3) }\end{array}$ & $\begin{array}{c}\text { Metal } \\
\text { factories } \\
(4)\end{array}$ & & $\begin{array}{c}\text { All } \\
\text { manufact. } \\
(6)\end{array}$ & $\begin{array}{c}\text { All except } \\
\text { metal+text. } \\
(7)\end{array}$ & $\begin{array}{l}\text { Metal } \\
\text { manufact. } \\
(8)\end{array}$ \\
\hline School enrollment rate 1849 & & $\begin{array}{c}0.079^{* * *} \\
(0.024)\end{array}$ & $\begin{array}{c}0.052^{* * *} \\
(0.018)\end{array}$ & $\begin{array}{c}0.015 \\
(0.010)\end{array}$ & & & & \\
\hline Literacy rate 1871 & & & & & & $\begin{array}{c}0.355^{* * *} \\
(0.049)\end{array}$ & $\begin{array}{c}0.162^{* * *} \\
(0.019)\end{array}$ & $\begin{array}{c}0.118^{* * *} \\
(0.032)\end{array}$ \\
\hline Distance to Wittenberg (in $1000 \mathrm{~km}$ ) & $\begin{array}{c}-0.276^{* * *} \\
(0.048)\end{array}$ & & & & $\begin{array}{c}-0.275^{* * *} \\
(0.033)\end{array}$ & & & \\
\hline Share of population living in cities 1816 & $\begin{array}{c}-0.147^{* * *} \\
(0.035)\end{array}$ & $\begin{array}{c}0.023^{* * *} \\
(0.008)\end{array}$ & $\begin{array}{l}0.011^{* * *} \\
(0.004)\end{array}$ & $\begin{array}{c}0.006 \\
(0.004)\end{array}$ & $\begin{array}{c}-0.061^{*} \\
(0.032)\end{array}$ & $\begin{array}{l}0.041^{* *} \\
(0.016)\end{array}$ & $\begin{array}{c}0.024^{* * *} \\
(0.005)\end{array}$ & $\begin{array}{c}0.001 \\
(0.008)\end{array}$ \\
\hline Looms per capita 1819 & $\begin{array}{c}0.188 \\
(0.158)\end{array}$ & $\begin{array}{l}0.130^{* * *} \\
(0.046)\end{array}$ & $\begin{array}{c}0.006 \\
(0.019)\end{array}$ & $\begin{array}{c}0.056 \\
(0.035)\end{array}$ & $\begin{array}{l}0.400^{* *} \\
(0.174)\end{array}$ & $\begin{array}{c}0.743^{* * *} \\
(0.288)\end{array}$ & $\begin{array}{l}-0.010 \\
(0.042)\end{array}$ & $\begin{array}{c}0.105 \\
(0.072)\end{array}$ \\
\hline Steam engines in mining per capita 1849 & $\begin{array}{c}0.045 \\
(0.043)\end{array}$ & $\begin{array}{l}0.039^{* * *} \\
(0.007)\end{array}$ & $\begin{array}{l}-0.002 \\
(0.004)\end{array}$ & $\begin{array}{c}0.037^{* * *} \\
(0.004)\end{array}$ & $\begin{array}{l}-0.005 \\
(0.049)\end{array}$ & $\begin{array}{c}0.178^{* * * *} \\
(0.016)\end{array}$ & $\begin{array}{c}0.002 \\
(0.009)\end{array}$ & $\begin{array}{l}0.194^{* * *} \\
(0.025)\end{array}$ \\
\hline Sheep per capita 1816 & $\begin{array}{l}-0.008 \\
(0.013)\end{array}$ & $\begin{array}{l}-0.002 \\
(0.002)\end{array}$ & $\begin{array}{c}0.001 \\
(0.001)\end{array}$ & $\begin{array}{l}-0.002^{*} \\
(0.001)\end{array}$ & $\begin{array}{c}0.021 \\
(0.014)\end{array}$ & $\begin{array}{c}-0.029^{* * *} \\
(0.006)\end{array}$ & $\begin{array}{c}-0.009^{* * *} \\
(0.002)\end{array}$ & $\begin{array}{c}-0.011^{* * *} \\
(0.003)\end{array}$ \\
\hline Share of farm laborers in total pop. 1819 & $\begin{array}{l}-0.245 \\
(0.154)\end{array}$ & $\begin{array}{l}-0.031 \\
(0.023)\end{array}$ & $\begin{array}{c}0.012 \\
(0.014)\end{array}$ & $\begin{array}{l}-0.015 \\
(0.009)\end{array}$ & $\begin{array}{c}-0.289^{* *} \\
(0.122)\end{array}$ & $\begin{array}{l}-0.022 \\
(0.063)\end{array}$ & $\begin{array}{c}0.039^{*} \\
(0.022)\end{array}$ & $\begin{array}{l}-0.041 \\
(0.036)\end{array}$ \\
\hline Public buildings per capita 1821 & $\begin{array}{c}6.758^{* * *} \\
(1.640)\end{array}$ & $\begin{array}{c}-0.844^{* * *} \\
(0.296)\end{array}$ & $\begin{array}{l}-0.292 \\
(0.207)\end{array}$ & $\begin{array}{c}-0.317^{* *} \\
(0.137)\end{array}$ & $\begin{array}{c}5.294^{* * *} \\
(1.635)\end{array}$ & $\begin{array}{c}-3.579^{* * *} \\
(0.707)\end{array}$ & $\begin{array}{c}-0.915^{* * *} \\
(0.269)\end{array}$ & $\begin{array}{c}-0.804^{*} \\
(0.421)\end{array}$ \\
\hline Paved streets 1815 (dummy) & $\begin{array}{c}0.015 \\
(0.009)\end{array}$ & $\begin{array}{c}0.002 \\
(0.002)\end{array}$ & $\begin{array}{l}0.002^{*} \\
(0.001)\end{array}$ & $\begin{array}{c}0.001 \\
(0.002)\end{array}$ & $\begin{array}{l}0.056^{* * *} \\
(0.009)\end{array}$ & $\begin{array}{l}-0.004 \\
(0.007)\end{array}$ & $\begin{array}{l}-0.001 \\
(0.002)\end{array}$ & $\begin{array}{c}0.004 \\
(0.004)\end{array}$ \\
\hline Tonnage of ships per capita 1819 & $\begin{array}{c}0.113 \\
(0.178)\end{array}$ & $\begin{array}{c}-0.032^{* *} \\
(0.015)\end{array}$ & $\begin{array}{l}-0.004 \\
(0.008)\end{array}$ & $\begin{array}{l}-0.013^{*} \\
(0.008)\end{array}$ & $\begin{array}{c}0.132 \\
(0.082)\end{array}$ & $\begin{array}{l}-0.027 \\
(0.039)\end{array}$ & $\begin{array}{l}0.018^{*} \\
(0.009)\end{array}$ & $\begin{array}{l}-0.008 \\
(0.023)\end{array}$ \\
\hline $\begin{array}{l}\text { Observations } \\
R^{2} \\
1^{\text {st }} \text {-stage } F \text { statistic }\end{array}$ & $\begin{array}{c}334 \\
0.478 \\
32.93 \\
\end{array}$ & $\begin{array}{c}334 \\
0.192\end{array}$ & $\begin{array}{c}334 \\
0.059\end{array}$ & $\begin{array}{c}334 \\
0.156\end{array}$ & $\begin{array}{c}334 \\
0.644 \\
68.45\end{array}$ & $\begin{array}{c}334 \\
0.598\end{array}$ & $\begin{array}{c}334 \\
0.416\end{array}$ & $\begin{array}{c}334 \\
0.501\end{array}$ \\
\hline
\end{tabular}

Notes: Instrumental-variable estimates, with school enrollment rate 1849 resp. literacy rate 1871 instrumented by distance to Wittenberg. Additional controls: share of population < 15 years, share of population > 60 years, county area (in $1000 \mathrm{~km}^{2}$ ), and a constant. Columns (1) and (5) report the first stages for columns (2)-(4) and (6)-(8), respectively. Standard errors (adjusted for clustering by 280 original counties) in parentheses: significance at ${ }^{* * *} 1$, $^{* *} 5{ }^{*} 10$ percent.

Source: Data for Prussian counties from different censuses; see Appendix A for details. 
TABle 8: AdDitional RoBustness SPECIFICATIONS

\begin{tabular}{|c|c|c|c|c|c|c|c|c|c|c|}
\hline \multirow[t]{3}{*}{ Dependent variable: } & \multicolumn{5}{|c|}{ Share of all factory workers 1849 in } & \multicolumn{5}{|c|}{ Share of all manufacturing workers 1882 in } \\
\hline & \multicolumn{4}{|c|}{ total population } & \multirow{2}{*}{$\begin{array}{c}\text { occupied } \\
\text { labor force } \\
(5)\end{array}$} & \multicolumn{4}{|c|}{ total population } & \multirow{2}{*}{$\begin{array}{l}\text { occupied } \\
\text { labor force } \\
\text { (10) }\end{array}$} \\
\hline & (1) & (2) & (3) & $(4)^{a}$ & & (6) & (7) & (8) & $(9)^{a}$ & \\
\hline School enrollment rate 1849 & $\begin{array}{c}0.039^{*} \\
(0.022)\end{array}$ & $\begin{array}{c}0.040^{*} \\
(0.022)\end{array}$ & $\begin{array}{l}0.043^{* *} \\
(0.017)\end{array}$ & $\begin{array}{l}0.057^{* *} \\
(0.028)\end{array}$ & $\begin{array}{l}0.092^{* *} \\
(0.042)\end{array}$ & & & & & \\
\hline Literacy rate 1871 & & & & & & $\begin{array}{l}0.095^{* *} \\
(0.043)\end{array}$ & $\begin{array}{c}0.080^{*} \\
(0.047)\end{array}$ & $\begin{array}{c}0.143^{* * *} \\
(0.040)\end{array}$ & $\begin{array}{l}0.101^{* *} \\
(0.042)\end{array}$ & $\begin{array}{l}0.257^{* *} \\
(0.104)\end{array}$ \\
\hline Share Protestants 1816 & $\begin{array}{c}0.003 \\
(0.002)\end{array}$ & & & & & $\begin{array}{c}0.002 \\
(0.007)\end{array}$ & & & & \\
\hline Share Jews 1816 & & $\begin{array}{c}-0.081^{* *} \\
(0.032)\end{array}$ & & & & & $\begin{array}{c}-0.180^{*} \\
(0.099)\end{array}$ & & & \\
\hline Year in which annexed by Prussia & & & $\begin{array}{c}-0.009 \\
(0.016)\end{array}$ & & & & & $\begin{array}{l}0.062^{* *} \\
(0.028)\end{array}$ & & \\
\hline Observations & 334 & 334 & 334 & 334 & 334 & 334 & 334 & 334 & 334 & 334 \\
\hline$R^{2}$ & 0.271 & 0.273 & 0.265 & 0.279 & 0.333 & 0.656 & 0.651 & 0.676 & 0.654 & 0.641 \\
\hline
\end{tabular}

Notes: Instrumental-variable estimates, with school enrollment rate 1849 resp. literacy rate 1871 instrumented by school enrollment rate 1816 . Additional controls: share of population $<15$ years, share of population $>60$ years, county area (in $1000 \mathrm{~km}^{2}$ ), share of population living in cities 1816, looms per capita 1819, steam engines in mining per capita 1849, sheep per capita 1816, share of farm laborers in total pop. 1819, public buildings per capita 1821, paved streets 1815 (dummy), tonnage of ships per capita 1819, and a constant. Standard errors (adjusted for clustering by 280 original counties) in parentheses: significance at ${ }^{* * *} 1,{ }^{* *} 5,{ }^{*} 10$ percent.

${ }^{a}$ In columns (4) and (9), school enrollment and literacy are measured as average of enrollment/literacy of each county and its neighboring counties.

Source: Data for Prussian counties from different censuses; see Appendix A for details. 
TABLE 9: GEOGRAPHICAL RoBUSTNESS SPECIFICATIONS

\begin{tabular}{|c|c|c|c|c|c|c|c|c|}
\hline "Dependent variable: & \multicolumn{4}{|c|}{ "Share of all factory workers in total pop. 1849} & \multicolumn{4}{|c|}{ "Share of all manufact. workers in total pop. 1882} \\
\hline & (1) & $(2)$ & (3) & (4) & (5) & (6) & (7) & (8) \\
\hline School enrollment rate 1849 & $\begin{array}{l}0.052^{* *} \\
(0.024)\end{array}$ & $\begin{array}{l}0.050^{* *} \\
(0.023)\end{array}$ & $\begin{array}{l}0.053^{* *} \\
(0.025)\end{array}$ & $\begin{array}{l}0.053^{* *} \\
(0.023)\end{array}$ & & & & \\
\hline Literacy rate 1871 & & & & & $\begin{array}{l}0.102^{* *} \\
(0.041)\end{array}$ & $\begin{array}{l}0.095^{* *} \\
(0.042)\end{array}$ & $\begin{array}{l}0.088^{* *} \\
(0.040)\end{array}$ & $\begin{array}{l}0.099^{* *} \\
(0.039)\end{array}$ \\
\hline Western part & $\begin{array}{c}0.001 \\
(0.003)\end{array}$ & & & & $\begin{array}{c}0.007 \\
(0.008)\end{array}$ & & & \\
\hline Polish parts & & $\begin{array}{c}-0.004^{* * *} \\
(0.002)\end{array}$ & & & & $\begin{array}{c}-0.018^{* *} \\
(0.007)\end{array}$ & & \\
\hline Distance to Berlin (in $1000 \mathrm{~km}$ ) & & & $\begin{array}{l}-0.005 \\
(0.008)\end{array}$ & & & & $\begin{array}{c}-0.066^{* * *} \\
(0.014)\end{array}$ & \\
\hline Dist. to next province capital (in $1000 \mathrm{~km}$ ) & & & $\begin{array}{c}0.031^{*} \\
(0.017)\end{array}$ & & & & $\begin{array}{c}0.167^{* * *} \\
(0.039)\end{array}$ & \\
\hline Distance to London (in $1000 \mathrm{~km}$ ) & & & $\begin{array}{c}-0.007^{* *} \\
(0.003)\end{array}$ & & & & $\begin{array}{c}-0.043^{* * *} \\
(0.011)\end{array}$ & \\
\hline Latitude (in rad) & & & & $\begin{array}{c}0.026 \\
(0.058)\end{array}$ & & & & $\begin{array}{c}-0.305^{* * *} \\
(0.101)\end{array}$ \\
\hline Longitude (in rad) & & & & $\begin{array}{c}-0.028^{* *} \\
(0.014)\end{array}$ & & & & $\begin{array}{c}-0.094^{* *} \\
(0.044)\end{array}$ \\
\hline Observations & 334 & 334 & 334 & 334 & 334 & 334 & 334 & 334 \\
\hline$R^{2}$ & 0.253 & 0.263 & 0.265 & 0.260 & 0.660 & 0.670 & 0.703 & 0.687 \\
\hline
\end{tabular}

Notes: Instrumental-variable estimates, with school enrollment rate 1849 resp. literacy rate 1871 instrumented by school enrollment rate 1816 . Additional controls: share of population < 15 years, share of population > 60 years, county area (in $1000 \mathrm{~km}^{2}$ ), share of population living in cities 1816, looms per capita 1819, steam engines in mining per capita 1849, sheep per capita 1816, share of farm laborers in total pop. 1819, public buildings per capita 1821, paved streets 1815 (dummy), tonnage of ships per capita 1819, and a constant. Standard errors (adjusted for clustering by 280 original counties) in parentheses: significance at ${ }^{* * *} 1,{ }^{* *} 5,{ }^{*} 10$ percent.

Source: Data for Prussian counties from different censuses; see Appendix A for details. 


\section{Appendix A: Data Sources}

We have compiled a county-level database covering all 334 Prussian counties (as of 1849) over virtually the whole $19^{\text {th }}$ century, from 1816 over 1849 to 1882 . The data were collected in several censuses by the Prussian Statistical Office, which we combine from several archives. We accounted for changes in the administrative boundaries of counties by adjusting all sources to the 1849 county borders. The county-level data for $19^{\text {th }}$-century Prussia is viewed by demographers as a unique source of highest-quality data for analyses at a micro-regional level (cf. Galloway, Hammel, and Lee 1994).

\section{Population and Establishment Censuses 1816, 1819, and 1821}

The Prussian Statistical Office, founded in 1805, started to publish detailed data at the county and municipality level in 1825. The data contain information from censuses in 1816, 1819, and 1821. The 1816 and 1821 censuses provide information on population, demography, religion, and livestock. Information on schooling is provided only in 1816 . The 1819 census provides data on establishments and means of production. These are, to our knowledge, the earliest censuses that lend themselves to a microeconometric analysis of education and pre-industrial endowments.

The 1819 and 1821 censuses are reported for 330 counties, four of which were later subdivided into two counties by 1849. The structure of 330 counties had been constructed by an administrative reform in 1812. By the time of the 1816 census, however, the reform had not yet been established in the original Eastern part of Prussia, where the old structure with larger counties was still in effect. The 1816 census is thus reported for 289 units of observation. We converted the data to match the 330 counties of the later censuses, based on population data from the 1821 census. Throughout the paper, counties are clustered at a level of 280 independent units of observation, based on the old structure and accounting for the fact that some counties had to be combined first before they could be subdivided again into the new structure.

The county-level data report on public elementary schools (Öffentliche Elementarschulen), the only school type equally available in rural areas and towns at the time. In addition, the 1816 census reports school data for the 172 medium and large towns in Prussia, which provide additional information on types of schools available only in towns: private elementary schools (Privat-Elementarschulen), public middle schools for boys or girls (Öffentliche Buerger- und Mittelschulen für Söhne oder Töchter), and private middle schools for boys or girls (Private 
Bürger- und Mittelschulen für Söhne oder Töchter). Children at recommended school age (6 to 14 years) could either attend elementary schools or middle schools, which had a broader curriculum as well as more grades. To capture all children at recommended school age, county and town enrollment data are aggregated to compute enrollment. ${ }^{16}$

The 1816, 1819, and 1821 censuses are also used to compute a rich set of control variables measuring pre-industrial development and demography (see Appendix Table A1).

The source of the 1816, 1819, and 1821 census data is Mützell (1825).

\section{Population, Schooling, and Factory Censuses 1849}

A collection of censuses from 1849 was published by the Prussian Statistical Office in seven volumes from 1851 to 1855. Our analyses employ the Population Census (Vol. 1), the Schooling Census (Vol. 2), and the Factory Census (Vol. 6a). All data are available for 334 counties.

The 1849 Schooling Census provides information on the number of schools, teachers, and students in public schools. The types of schools employed in our analysis are public elementary schools (Öffentliche Elementarschulen) and public middle schools for boys (Öffentliche Mittelschulen für Söhne) and for girls (Öffentliche Schulen für Töchter, die nicht in den Begriff der Elementarschule fallen). Children at recommended school age (6 to 14 years) could either attend elementary schools or middle schools, so that data are again aggregated.

The 1849 Factory Census provides information on the number of factories, machinery, and workers per factory for each county. It distinguishes 119 types of factories by the products fabricated. We calculated the share of factory workers in the total population. We also subdivide factories into three industrial sectors: workers in metal factories, workers in textile factories, and workers in all other factories except metals and textiles. The first sector includes processing of metals and production of metal products and machinery, as well as manufacture of stone and glass products. The second sector includes factories for spinning, weaving, dyeing, and apparel. The third sector includes factories that produce such products as rubber, paper, food, wood, and wax. In the textile sector, workers working on hand-driven looms and weavers working for their own accounts were not counted as industry workers.

\footnotetext{
${ }^{16}$ The 1816 school enrollment data were missing for the eleven counties of the district of Cologne. We imputed the data based on school enrollment data available in 1829 for all 59 counties of the Rhine Province (Preussisches Statistisches Landesamt 1829). Given a high correlation of 0.59 of the 1829 data with the 1816 data for the 48 counties with both datasets available, we regressed the 1816 data on the 1829 data and predicted the 1816 values for the eleven Cologne counties based on their 1829 values.
} 
The 1849 Factory Census also includes information on steam engines in different industries. We included steam engines employed in mining in our dataset.

The source of the 1849 census data is Statistisches Bureau zu Berlin (1851-1855).

\section{Population Census 1871}

The 1871 Population Census collected information on demographics, religion, and education. This is explicitly the very first census to ever survey literacy in Prussia. Literacy is measured as the ability to read and write among the population aged 10 years and older.

The source of the 1871 census data is Königliches Statistisches Bureau (1874).

\section{Occupation Census 1882}

The 1882 Occupation Census collected information on employment and self-employment across two-digit sectors for the Prussian counties. We calculate the share of manufacturing workers in the total population. The manufacturing sector is also subdivided into three subsectors: manufacturing of metals, manufacturing of textiles, and all manufacturing except metals and textiles. The sectors are computed to match the sectors of the 1849 Factory Census using the classification provided by the Prussian Statistical Office. The first sector includes mining, products from stone, glass and metals, machinery, and chemicals. The second sector includes textile, apparel, and cleaning industries. The third sector includes such manufacturing as paper, food, wood, and construction industries.

The source of the 1882 census data is Preussische Statistik (1884/85).

\section{Additional Appendix References}

Galloway, Patrick R., Eugene A. Hammel, Ronald D. Lee (1994). Fertility Decline in Prussia, 1875-1910: A Pooled Cross-Section Time Series Analysis. Population Studies 48 (1): 135158.

Königliches Statistisches Bureau (1874). Die Gemeinden und Gutsbezirke des Preussischen Staates und ihre Bevölkerung: Nach den Urmaterialien der allgemeinen Volkszählung vom 1. December 1871. Berlin: Verlag des Königlichen Statistischen Bureaus.

Mützell, Alexander A. (1825). Neues Topographisch-statistisch-geographisches Wörterbuch des Preussischen Staats. Halle: Karl August Kümmel.

Preussische Statistik (1884/85). Die Ergebnisse der Berufsstatistik vom 5. Juni 1882 im preussischen Staat, Vol. 76. Berlin: Verlag des Königlichen Statistischen Bureaus.

Preussisches Statistisches Landesamt (1829). Beiträge zur Statistik der Königlichen Preussischen Rheinlande, aus amtlichen Nachrichten zusammenstellt. Aachen: J.A. Mayer.

Statistisches Bureau zu Berlin (1851-1855). Tabellen und amtliche Nachrichten über den Preussischen Staat für das Jahr 1849, Vol. 1-6b. Berlin: Statistisches Bureau zu Berlin. 


\section{Appendix B: The Relevance of Education for Industrialization}

What is it that makes education relevant for industrialization, even in the first phase of the Industrial Revolution? Which types of education and curricular content facilitate the adoption of the new technical and organizational modes? We can only speculate on this, but it seems useful to classify different dimensions in which education may be relevant for industrial development and relate them to discussions in the literature and to our results. For the latter, we focus on the role of school education and basic literacy of the population at large in facilitating the regional emergence and growth of factories that use the new industrial technologies.

A first dimension in which education could facilitate industrial development is its role for entrepreneurship (cf. Kocka 1977 for a discussion in the Prussian setting and Bates 1990 as an example of modern evidence). Education may impart higher-level scientific skills and the ability to innovate necessary to advance technical knowledge. While this may seem foremost the task of higher education (for which we do not find significant effects), ${ }^{17}$ it has been argued that a system of basic education that covers the broad masses is a pre-requisite to screen the highest-capable entrepreneurs and researchers. Thus, Landes (1980, p. 118) argues that “elementary schooling as such has been important ... as a device for the recruitment of talent. ... the bigger the pool one draws from, the better the chances of finding gifted and original scientists and technicians.” Although this genuinely innovative dimension of the role of education may have gained relevance in some sectors (such as certain electrical and chemical industries) during the second phase of Prussian industrialization, the foremost task relevant for early Prussian industrialization rather seems to have been imitation.

A second dimension at the other extreme is the direct productive use of skills, at work even in a purely stationary economy. If the tasks of a factory require a certain minimum level of skills, such as the ability to read basic instructions and perform basic calculations, then an entrepreneur cannot establish and run a factory in a region where the whole population lacks basic literacy. Formal education may also impart behavioral traits and non-cognitive skills that are relevant for factory production, such as conscientiousness, dependability, self-control, discipline, punctuality, responsibility, orderliness, and perseverance (e.g., Field 1989; Bowles, Gintis, and Osborne 2001). In addition, industrial production creates service jobs that require literacy and numeracy

\footnotetext{
${ }^{17}$ Higher education may also not have been particularly oriented towards technical sciences or economically usable skills in Germany at the time (Weber 2003).
} 
skills, such as accountancy, commercial transactions, banking, insurance, and lawyers (e.g., Anderson and Bowman 1976; Allen 2009). As Laqueur (1974, p. 103) argues, the industrial "economy require[d] supervisory personnel ... [and] created a whole mass of ancillary jobs in engineering, transport, trade, retailing, finance and the older artisanal trades.”

Although both static skills and purely innovative abilities may have their relevance for industrialization in $19^{\text {th }}$-century Prussia, it seems that rather a third dimension is of prime importance in the context of industrial catch-up: the role of education in the adoption of new technologies. In motivating their catch-up model of technological diffusion, Nelson and Phelps (1966, p. 69) argue that "probably education is especially important to those functions requiring adaptation to change. Here it is necessary to learn to follow and to understand new technological developments." This dimension of education, the ability to adjust to changing conditions, seems of particular importance in the Prussian setting after 1815, where the Stein-Hardenberg reforms unleashed the potential to adapt to the changed environment of newly available technologies.

In a dynamic setting of changing technology, education plays a particular role by fostering the "ability to deal with disequilibria" (Schultz 1975), i.e., to perceive a given disequilibrium, to evaluate its attributes properly in determining whether it is worthwhile to act, and to undertake action to appropriately reallocate resources. Such abilities are particularly relevant when technical change is disruptive rather than incremental, as is the case for most industries emerging during the Industrial Revolution (with the possible exception of textiles, see Section V). Education may enhance "allocative ability in the sense of selecting the appropriate input bundles and of efficiently distributing inputs between competing uses” (Welch 1970, p. 55). According to Schultz (1975, p. 835), “The presumption is that education - even primary schooling - enhances the ability of students to perceive new classes of problems, to clarify such problems, and to learn ways of solving them. ... [These] abilities ... seem to have general properties that contribute measurably to their performance as economic agents in perceiving and solving the problems that arise as a consequence of economic changes.” Because this type of economic returns to education accrues only in a technically dynamic context, not in a static economy with stationary technology (see Bartel and Lichtenberg 1987; Foster and Rosenzweig 1996 for examples of modern evidence), the relatively high Prussian education level may not have been of similar economic relevance before the institutional reforms of the first two decades of the $19^{\text {th }}$ century. 
The skills necessary in this setting are multifaceted and general, rather than applied to one particular craft, and may be best described as a general understanding of the functioning of the world. They start with the basic "three R's" of reading, writing, and arithmetic, required for commercial communication, accessing practical handbooks, decoding instructions, debugging new processes, reading books about foreign places - all relevant actions in the given historical setting (Anderson and Bowman 1976). ${ }^{18}$ They may also encompass socialization and the creation of an aspiring human personality with attitudes favorable to adopting new technology (Easterlin 1981). Finally, literacy may create awareness of nonconventional possibilities; as Anderson and Bowman (1976, p. 7) put it, "Almost every effect of literacy includes an element of change in men's perceptions of the alternatives in action that are open to them." Note that the ability to reallocate one's resources in response to changing conditions and the ability to discover and master new tasks is not restricted to entrepreneurs, but is useful and required for basically any economic activity at all stages of management and production (cf. Schultz 1975).

The Prussian school system that emerged at the start of the $19^{\text {th }}$ century may have been particularly capable of delivering the abilities that are productive in this setting. Its educational ideal of an encompassing education aimed at providing the broad masses with the competency to think rationally and to act independently as a human being (see Section V). Even though the Industrial Revolution may initially have created demand for uneducated labor - and often child labor - to perform routine tasks in some industries, our evidence suggests that the previous arguments of the role of education in creating the ability to adjust to changing conditions may have been of resounding relevance in both phases of the Industrial Revolution in Prussia.

\section{Additional Appendix References}

Anderson, C. Arnold, Mary J. Bowman (1976). Education and Economic Modernization in Historical Perspective. In: Lawrence Stone (ed.), Schooling and Society: Studies in the History of Education, pp. 3-19. Baltimore, Maryland: Johns Hopkins University Press.

Bartel, Ann P., Frank R. Lichtenberg (1987). The Comparative Advantage of Educated Workers in Implementing New Technology. Review of Economics and Statistics 69 (1): 1-11.

Bates, Timothy (1990). Entrepreneur Human Capital Inputs and Small Business Longevity. Review of Economics and Statistics 72 (4): 551-559.

Bowles, Samuel, Herbert Gintis, Melissa Osborne (2001). The Determinants of Earnings: A Behavioral Approach. Journal of Economic Literature 39 (4): 1137-1176.

18 In a similar vein, Vandenbussche, Aghion, and Meghir (2006) stress the particular role of primary and secondary education (as opposed to tertiary education) in the imitation process. 
Field, Alexander J. (1989). Educational Reform and Manufacturing Development in MidNineteenth Century Massachusetts. New York: Garland.

Foster, Andrew D., Mark R. Rosenzweig (1996). Technical Change and Human-Capital Returns and Investments: Evidence from the Green Revolution American Economic Review 86 (4): 931-953.

Kocka, Jürgen (1977). Entrepreneurship in a Late-comer Country: The German Case. In: Keiichiro Nakagawa (ed.), Social Order and Entrepreneurship, pp. 149-198. Tokyo: University of Tokyo Press.

Landes, David S. (1980). The Creation of Knowledge and Technique: Today's Task and Yesterday's Experience. Daedalus 109 (1): 111-120. 
Figure A1: FACTORY WORKERS IN THE FIRST PHASE OF THE INDUSTRIAL REVOLUTION IN PRUSSiA 1849

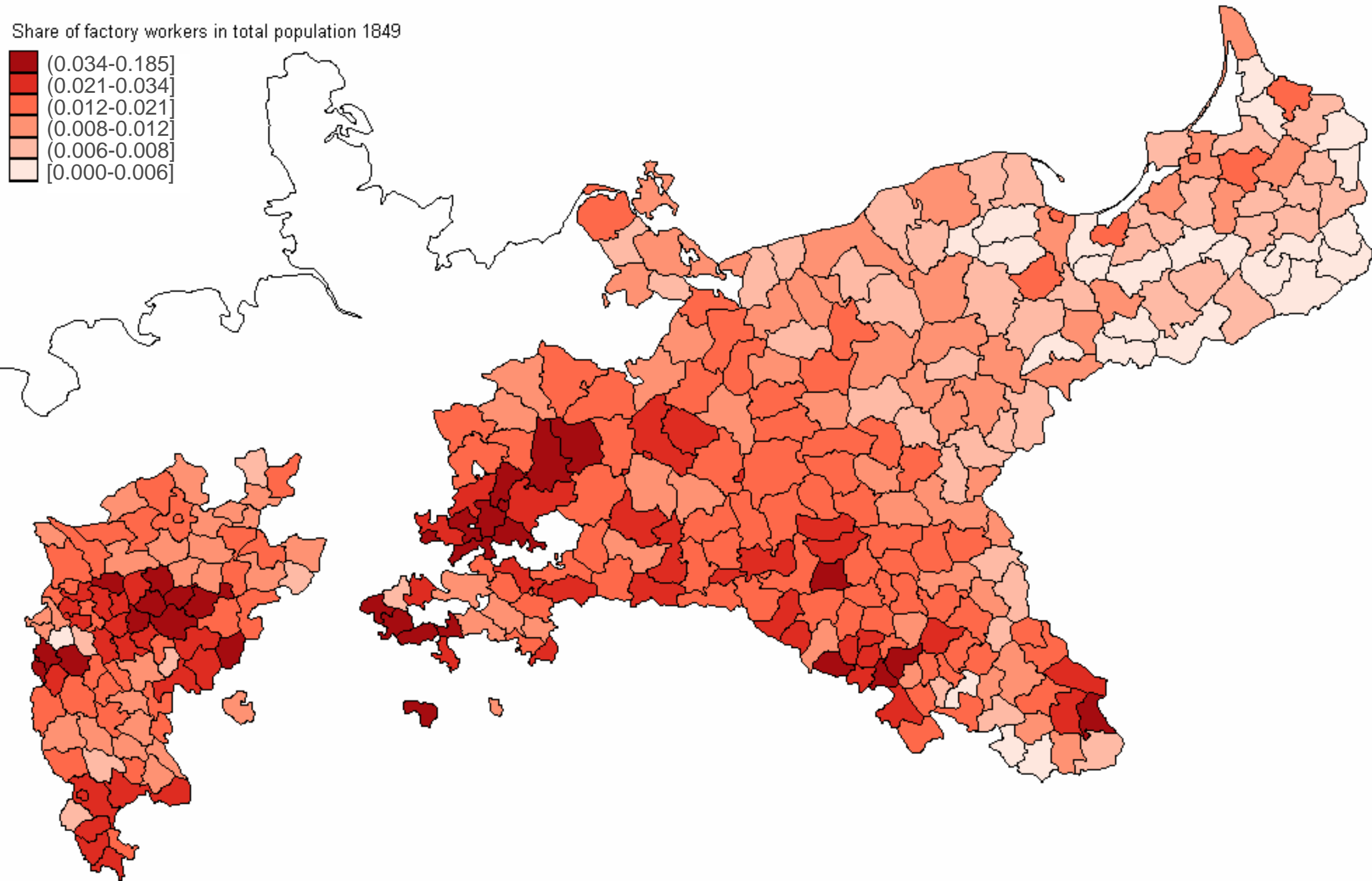

Notes: County-level depiction based on the 1849 Factory Census. The delimiters correspond roughly to the $10^{\text {th }}, 25^{\text {th }}, 50^{\text {th }}, 75^{\text {th }}$, and $90^{\text {th }}$ percentile of the variable. See Appendix A for data details. 


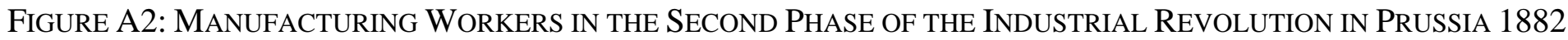

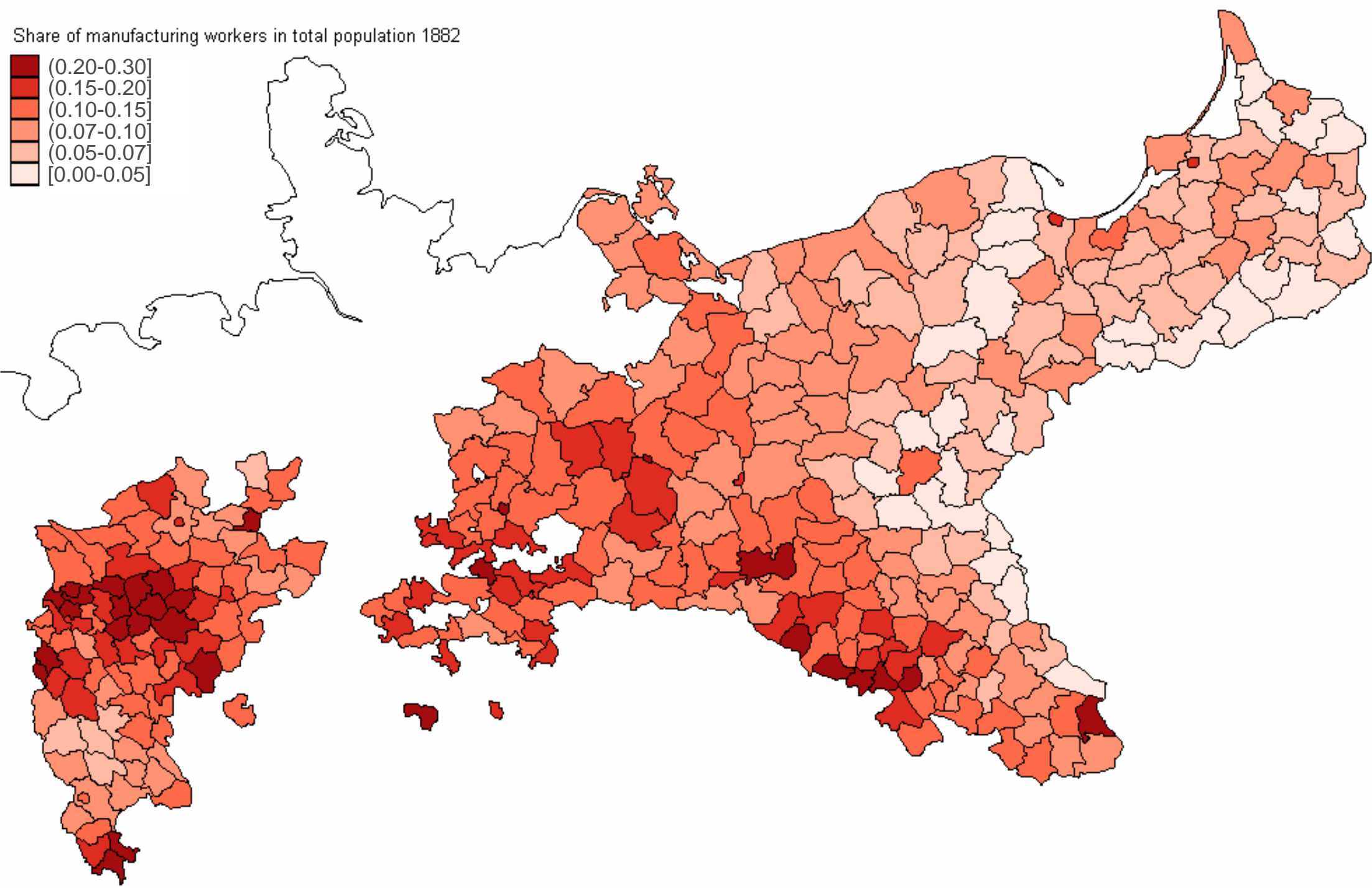

Notes: County-level depiction based on the 1882 Occupation Census. The delimiters correspond roughly to the $10^{\text {th }}, 25^{\text {th }}, 50^{\text {th }}, 75^{\text {th }}$, and $90^{\text {th }}$ percentile of the variable. See Appendix A for data details. 
TABLE A1: DATA DESCRIPTIONS AND SOURCES

\begin{tabular}{|c|c|c|}
\hline Variable & Source & Description \\
\hline \multicolumn{3}{|l|}{ Education measures: } \\
\hline School enrollment rate 1816 & Population Census 1816 & $\begin{array}{l}\text { Enrollment in elementary and middle schools divided by population aged } 6 \\
\text { to } 14\end{array}$ \\
\hline School enrollment rate 1849 & Schooling Census 1849 & $\begin{array}{l}\text { Enrollment in elementary and middle schools divided by population aged } 6 \\
\text { to } 14\end{array}$ \\
\hline Literacy rate 1871 & Population Census 1871 & $\begin{array}{l}\text { Population older than } 10 \text { with ability to read and write divided by total } \\
\text { population older than } 10\end{array}$ \\
\hline \multicolumn{3}{|l|}{ Share of factory workers in total population 1849: } \\
\hline All factories & Factory Census 1849 & Employment in factories divided by total population \\
\hline All factories except metals and textiles & Factory Census 1849 & $\begin{array}{l}\text { Employment in factories other than metal and textile factories divided by } \\
\text { total population }\end{array}$ \\
\hline Metal factories & Factory Census 1849 & Employment in metal factories divided by total population \\
\hline Textile factories & Factory Census 1849 & Employment in textile factories divided by total population \\
\hline Share of all factory workers in occupied labor force & Factory Census 1849 & Employment in factories divided by total occupation count \\
\hline \multicolumn{3}{|l|}{ Share of manufacturing workers in total population 1882 : } \\
\hline All manufacturing & Occupation Census 1882 & Employment in manufacturing divided by total population \\
\hline All manufacturing except metals and textiles & Occupation Census 1882 & $\begin{array}{l}\text { Employment in manufacturing other than metals and textiles divided by } \\
\text { total population }\end{array}$ \\
\hline Metal manufacturing & Occupation Census 1882 & Employment in manufacturing of metals divided by total population \\
\hline Textile manufacturing & Occupation Census 1882 & Employment in manufacturing of textiles divided by total population \\
\hline Share of all manuf. workers in occupied labor force & Occupation Census 1882 & Employment in manufacturing divided by total occupation count \\
\hline \multicolumn{3}{|l|}{ Basic demographic and geographic measures: } \\
\hline Share of population $<15$ years 1849 & Population Census 1849 & Population younger than 15 divided by total population \\
\hline Share of population > 60 years 1849 & Population Census 1849 & Population older than 60 divided by total population \\
\hline County area (in 1000 km²) & Population Census 1816 & Total area of the county in $1000 \mathrm{~km}^{2}$, excluding expanse of water \\
\hline
\end{tabular}

(continued on next page) 
TABLE A1 (CONTINUED)

\begin{tabular}{|c|c|c|}
\hline Variable & Source & Description \\
\hline \multicolumn{3}{|l|}{ Pre-industrial development: } \\
\hline Share of population living in cities 1816 & Population Census 1816 & Population living in a town having city rights divided by total population \\
\hline Looms per capita 1819 & $\begin{array}{l}\text { Establishment Census } \\
1819\end{array}$ & Sum of looms on different fabrics divided by total population \\
\hline Steam engines in mining (per 1000 inhabitants) 1849 & Factory Census 1849 & Steam engines employed in mining per 1000 inhabitants \\
\hline Sheep per capita 1816 & Population Census 1816 & Sheep (Landschafe) divided by total population \\
\hline Share of farm laborers in total population 1819 & $\begin{array}{l}\text { Establishment Census } \\
1819\end{array}$ & Domestic workers (Dienstboten) in agriculture divided by total population \\
\hline Public buildings per capita 1821 & Population Census 1821 & $\begin{array}{l}\text { Public buildings for state or public purpose divided by total population (not } \\
\text { including churches) }\end{array}$ \\
\hline Paved streets 1815 (dummy) & $\begin{array}{l}\text { Calculated following } \\
\text { Königliches Handelsamt } \\
\text { zu Berlin (1847) }\end{array}$ & Dummy $=1$ if county had access to one or more paved streets (Chaussee) \\
\hline $\begin{array}{l}\text { Tonnage of transport ships (in } 4000 \text { p) per capita } \\
1819\end{array}$ & $\begin{array}{l}\text { Establishment Census } \\
1819\end{array}$ & $\begin{array}{l}\text { Total tonnage capacity of river transport ships (in } 4000 \text { pound) divided by } \\
\text { total population }\end{array}$ \\
\hline \multicolumn{3}{|l|}{ Additional demographic and geographic measures: } \\
\hline Distance to Wittenberg (in 1000 km) & & Distance of county’s capital to Wittenberg in $1000 \mathrm{~km}$ \\
\hline Share Protestants 1816 & Population Census 1816 & Lutherans and reformed Protestants divided by total population \\
\hline Share Jews 1816 & Population Census 1816 & Jews divided by total population \\
\hline Year in which annexed by Prussia (divided by 1000) & & Year in which county became part of Prussia divided by 1000 \\
\hline Western part & & Dummy = 1 if county in provinces Rhineland or Westphalia \\
\hline Polish parts & & Dummy = 1 if county located in Poland today \\
\hline Distance to Berlin (in 1000 km) & & Distance of county’s capital to Berlin in $1000 \mathrm{~km}$ \\
\hline Distance to next province capital (in $1000 \mathrm{~km}$ ) & & Distance of county’s capital to closest province capital in $1000 \mathrm{~km}$ \\
\hline Distance to London (in 1000 km) & & Distance of county's capital to London in $1000 \mathrm{~km}$ \\
\hline Latitude (in rad) & & Latitude (in rad) \\
\hline Longitude (in rad) & & Longitude (in rad) \\
\hline
\end{tabular}

